\title{
The Investigation of Prospective Mathematics Teachers' Metaphorical Perceptions Regarding Technology ${ }^{1}$
}

\author{
Emine Özdemir \\ Department of Mathematics Education, Faculty of Necatibey Education, Balikesir University, Balıkesir, Turkey
}

\begin{abstract}
The study aimed to investigate prospective mathematics teachers' perceptions related to technology. The behaviors, meanings, perceptions and experiences related to concepts can be defined through phenomenological approach. For this reason, phenomenological research design was used in this study and the prospective mathematics teachers' metaphors for aspects of technology were collected as data. In order to explore the metaphors for aspects of technology, the prospective teachers were asked to provide written answers to questions such as: "Technology is like ..., because...". The participants in the study were second-, third- and fourth-grade prospective teachers studying in the Mathematics Education Department of the Necatibey Faculty of Education at Balıkesir University. They were chosen by simple random sampling. The qualitative data related to the prospective teachers' metaphorical perceptions were coded thematically, and frequency and percentages were calculated. With this study, it has been revealed that the perceptions of the prospective mathematics teachers regarding technology are quite diversified and mostly positive. In this study, it has been concluded that metaphors can be used as an important research tool to explain the perceptions of prospective teachers regarding "technology".
\end{abstract}

Keywords: mathematics education, metaphors, prospective mathematics teachers, technology.

\section{Introduction}

As in many other fields, the developments in the fields of science and technology directly affect the education process. The technology which occupies an important place in our lives developed in a relatively short period of time. This technology has paved the way for innovations in the field of education, and has paved the way for improvement and the acceleration of learning for the existing personnel in this field. The Mathematics Curriculum (MC) also has continuously been updated in parallel with developments in science and technology. MC is based on the Turkish Qualifications Framework which is designated as a national framework of qualifications that shows the qualification principles acquired through vocational, general, academic curricula including primary, secondary and higher education and all other education methods. In this framework, there exist eight key qualifications and it draws attention to mathematical qualification, science/technology qualification and today's improved technology perception via digital competency (Mathematics Curriculum, 2017: 5-6).

The National Council of Teachers of Mathematics (NCTM) highlights the importance of the use of digital technologies in teaching mathematics under the scope of technology principle. Mathematics education is improved with the use of technology, technology contributes to the teaching of mathematics, and the quality of mathematics education increases (NCTM, 2000, 25-26, as cited in Yanpar-Yelken, Sancar-Tokmak, Özgelen, \& İnkab1, 2013:9). According to the Association of Mathematics Teacher Educators (AMTE), the curricula need to assure the proper environments for teachers in order to enable them to integrate technology into mathematics education content (AMTE, 2006, as cited in Öksüz, Ak, \& Uça, 2009). Studies have shown that teacher qualifications have a great effect on the success of students (Darling-Hammond, 2000; Rockoff, 2003; Goe \& Stickler, 2008; as cited in Ted, 2009). In this respect, the integration of the field knowledge, pedagogical knowledge, and education technologies gains importance in the curricula of faculties of education.

The importance of teachers' qualifications regarding the integration of technology in teaching is more important than ever in today's education system. The current development and dissemination of technology in daily life created the necessity of diversity and innovation in educational methods. Therefore, in education today, teachers need to fully prepare themselves in order to acquire the complex qualifications necessary in using the technological instruments that are required in their occupation. Studies in recent years have highlighted the technological-pedagogical field knowledge of teachers in general. Nowadays, teachers are expected to have knowledge about the curricula and subject field, as well as knowing how to teach the curriculum. Teachers must also be familiar with and knowledgeable about the relationship of the field to other fields, the latest developments in the field, the basic concepts, tools and structures of the field, and the integration of the content with technology. Along with this, the template curriculum for mathematics education encourages the use of information and communication technologies in mathematics education. The students' use of information and

\footnotetext{
${ }^{1}$ This study has been presented at the 8th International Conference on New Horizons in Education (INTE 2017, July 17-19, Berlin)
} 
communication technologies can help them interpret the concepts, and discover the relationships among these concepts. These technologies are important in paving the way for students to develop different approaches, conduct sound reasoning, and make mathematical generalizations (MoNE, 2017). In conclusion, prospective teachers need to display their technical skills and be proficient in the use of technology, as well as be able to use these technologies in their teaching methods.

The prospective teachers' perspectives towards technology are of high importance. These perspectives can help them benefit from technology more efficiently and productively (Çelik \& Kahyaoğlu, 2007). Determining the perceptions of prospective teachers towards technology enables can reveal their thoughts about technology, and the attitudes that they developed based on their perceptions and previous experiences. Metaphors are the most powerful mental instruments that can be used to reveal the prospective teachers' perceptions towards the concept of technology; these are the metaphors that they use regarding these concepts when the studies in this field are investigated.

In a study by Arslan and Zengin (2017) the metaphors developed by the prospective science teachers are divided into nine categories. The categories for the technology metaphors produced are as "a need", "a process that constantly changes and improves", "harmful", "beneficial", "addictive", "both harmful and beneficial", "enlightening", "a means to knowledge", and "making life easier". The respective order of the most frequent metaphors produced by the prospective teachers is: "a process that constantly changes and improves", "harmful and beneficial", "beneficial", and "a need". Additionally, the metaphors regarding the concept of technology are also observed to be clustered around the "harmful" category, which revealed that there is a critical view towards techno logy as well. In a study by Erdoğan and Gök (2008), the prospective teachers produced 285 metaphors towards the concept of technology. The categories regarding the metaphors produced by the prospective teachers are "a need", "ever-changing", "improving", "harmful", "beneficial", "addictive", "both harmful and beneficial", "rapidly progressive", and "making life easier". The 82 metaphors regarding technology in Fidan's (2014) study were placed into eight categories as "a need", "development-change", "a source of knowledge", "infinity", "both beneficial and harmful", "beneficial", "harmful", and "others". In Kurt and Özer's study, 83 different metaphors were collected from 120 prospective teachers. The metaphors were classified under seven categories as "technology makes life easier", "beneficial technology", "harmful technology", "both beneficial and harmful technology", "developing technology", "a means to knowledge technology", and "necessary technology". When the categories were considered as a whole, the most frequent categories reported by the prospective teachers were found to be "instrument" (15), and "life" (10). When the categories are considered separately, the most frequently occurring category was found to be "both beneficial and harmful technology". In addition to this, the most frequent metaphor produced under the category "a necessary technology" was found as "life"; the most frequent metaphor under the category "technology makes life easier" was found as "instrument". No significant difference was found when the metaphors were analyzed in relation to gender or different undergraduate programs.

104 prospective teachers participated in Kobak and Taşkın's (2012) study. The conceptual categories developed based on the teachers' metaphors regarding the concept of technology were defined as: 1) changing and developing, 2) rapidly progressing, 3) limitless and infinitive, 4) beneficial, 5) harmful, 6) both beneficial and harmful, 7) part of daily life, and 8) necessary and technology including anything. Yalçın and Küçük (2016) in their study with 160 prospective teachers investigated the prospective teachers' perceptions regarding technology by means of metaphors. The results of the study revealed eight conceptual categories of technology as: 1) necessary, 2) ever-changing, 3) developing, 4) beneficial, 5) an addiction, 6) both beneficial and harmful, 7) rapidly developing and 8) enhancing the quality of life. Gök and Erdoğan (2010) in their study described the perceptions of 560 university students towards the concept of technology by means of metaphors. The results of the study revealed nine categories of technology as 1) necessary, 2) ever-changing, 3) developing, 4) harmful, 5) beneficial, 6) an addiction, 7) both beneficial and harmful, 8) constantly developing and 9) makes life easier. In a study by Karaçam and Aydın (2014), 163 valid metaphors produced by secondary school student teachers regarding the concept of technology revealed eight conceptual categories as: 1) beneficial, 2) both beneficial and harmful, 3) limitless and infinitive, 4) ever-changing, 5) rapidly developing, 6) necessary, 7) rapidly disseminating and 8) developing. In a study by Korkmaz and Ünsal (2016), 57 metaphors regarding the concept of technology were produced by 76 preschool student teachers. With reference to the common traits of the 57 metaphors produced by the teachers, six categories were formed. Among the metaphors, the most frequent one was the perception of technology as a medicine $(\mathrm{f}=8)$. Among the preschool student teachers $11(14.5 \%)$ of them perceived technology negatively, $20(23.7 \%)$ of them perceived technology positively, $7(10.5 \%)$ of them perceived technology as infinity, 8 (11.8) of them perceived technology as a living thing, $24(31.6 \%)$ of them perceived s technology as a need, and $6(7.9 \%)$ of them perceived technology as life. Durukan, Haciğulu, and Dönmez-Usta (2016) revealed in their study that 103 metaphors produced by the prospective teachers fall into the categories related to the positive aspects of technology. The rate is $100 \%$, and this category included 17 subcategories including renewal, progress, development, change, the source of knowledge/teaching, facilitation, 
being beneficial, dissemination, producing, communication, need, arrive, enjoy, infinity, enlightening, interesting, and the main branch. Seven metaphors produced by $11.32 \%$ of the prospective teachers were placed into the category of negative aspects of technology. This category was divided into two sub-categories as being harmful and being addictive. Eight metaphors produced by $13.20 \%$ of the prospective teachers were placed into the category of technology's neutral aspects. In this category, there are two sub-categories which include the goodbad aspects of technology. At the end of the study, the prospective teachers of computer and education technologies generally perceived technology through positive aspects; however, some of them perceived the negative and neutral aspects, as well.

Many studies in the literature have investigated the perceptions of individuals towards technology (e.g., Raat \& de Vries, 1985; Rennie \& Javis, 1995; Moreland, 2004; Erdoğan \& Gök, 2008; Gök \& Erdoğan, 2010; Küçük and Yalçın, 2011; Kurt \& Erişti, 2011; DiGironimo, 2011; Karadeniz, 2012; Kobak \& Taşkın, 2012; Kurt $\&$ Özer, 2013). However, metaphorical perceptions of prospective teachers towards technology were found to be missing in many of the studies (Erdoğan \& Gök, 2008; Gök \& Erdoğan, 2010; Yalçın \& Küçük, 2011; Kobak \& Taşkın, 2012; Kurt \& Özer, 2013; Fidan, 2014). In this respect, positive attitudes can be developed in prospective teachers and their awareness can be raised after determining their perceptions during the pre-service stage. It is believed that determining prospective teachers' perceptions regarding technology can enable them to effectively use technology in the educational environment, and can contribute to their education and learning.

Teacher training institutions have an important role in developing and enriching the curricula in education, and supporting the courses with the latest technological instruments and applications. In this respect, training modern students can only be possible with teachers who are using modern education methods. Therefore, the faculties in teacher training institutions are expected to help the prospective teachers develop into individuals who are equipped with the necessary information and experiences in terms of technology (Fisher, 1996; Gronseth et al., 2010; as cited in Saygıner, 2016). Considering this, the purpose of this study is to investigate the perceptions of $2^{\text {nd }}, 3^{\text {rd }}$, and $4^{\text {th }}$-grade prospective mathematics teachers towards the concept of technology by means of metaphor analysis. In line with this, the current study sought answers to the questions: "Which metaphors are preferred by the prospective mathematics teachers?", and "Why are these metaphors preferred?" .

\section{Methodology}

2.1 Research design

The purpose of this study is to reveal the metaphorical perceptions of prospective mathematics teachers regarding technology. The behaviors, meanings, perceptions, and experiences regarding the concepts can be described through the phenomenology approach (Yıldırım \& Şimşek, 2008). Therefore, a phenomenology design was adopted for the qualitative aspect of the study. The perceptions of prospective teachers regarding technology were investigated by means of metaphors. Metaphors are considered as a powerful mental instrument that an individual can use in understanding and describing a highly abstract, complex, or theoretical phenomenon (Saban, Koçbeker, \& Saban, 2006).

\subsection{Participants}

The participants of the study is composed of $2^{\text {nd }}, 3^{\text {rd }}$, and $4^{\text {th }}$ grade prospective teachers $\left(852^{\text {nd }}\right.$ grade, $493^{\text {rd }}$ grade, and $394^{\text {th }}$ grade) from the Department of Elementary Mathematics Education of the Educational Faculty at Balıkesir University. Participants were selected through a simple random sampling method. This sampling method provides an equal opportunity for prospective teachers to be selected for the study group. In this study, $78 \%$ of the students studying to be $2^{\text {nd }}, 3^{\text {rd }}$, and $4^{\text {th }}$ grade teachers in the undergraduate program of elementary mathematics teacher education were accessed. This ratio was $89 \%$ for second-grade prospective teachers, $50 \%$ for third-grade prospective teachers, and $48 \%$ for fourth-grade prospective teachers.

\subsection{Data Collection and Analysis Procedure}

Attempts to collect data through metaphors are not much different from individual or focus group interviews based on open-ended questions. Due to the nature of the data, it is an easier and more practical data collection method compared to other methods, such as individual or focus group interviews, observation or some varieties of document analysis. This is because, when used alone, it is possible to obtain quite rich metaphors from the participants by means of one or more open-ended questions in a typical metaphor-focused qualitative data collection process (Yıldırım \& Şimşek, 2008). In this respect, the qualitative data were gathered with the help of an interview form developed by the researcher, a form which included open-ended questions. The question "Technology is like ..., because..." was given to the prospective teachers in order to investigate their perceptions regarding the concept of technology. They were asked to write at least three sentences. Descriptive analysis was conducted to collect the qualitative data. The qualitative data regarding the prospective teachers' metaphorical perceptions and explanations for these metaphors in relation to technology were thematically coded, and frequencies and percentages were calculated. The reliability of the study was calculated through the Miles and 
Huberman's (1994) [Agreement/ (Agreement + Disagreement) X 100] formula. In qualitative studies, a percentage above 90\% regarding the consistency between the evaluation of the experts and the researchers is considered as sufficient for reliability. In the evaluation of the qualitative data, two experts were consulted apart from the researcher. The reliability for the metaphorical perceptions was calculated as $94 \%$. Therefore, the validity and reliability of the study were ensured.

\section{Results}

Prospective teachers' metaphorical perspectives towards technology were investigated through descriptive analysis, and a thematic coding procedure was followed. A total of 567 metaphors were produced by the prospective teachers. These metaphors were analyzed with the experts in the field considering the literature, and the results were classified under 8 themes based on the common traits of the metaphors. These themes are positive effects of technology, negative effects of technology, technology by the purpose of use, the structural features of technology, the contributions of technology to the student, the contributions of technology to the teacher, developing a positive attitude towards technology, and developing a negative attitude towards technology.

When the metaphorical perceptions in Table 1 were investigated, it can be determined that the prospective second-grade teachers frequently used "human (25)", "mathematics (14)", "game (8)", "life (8)", "tree (8)", "forest (7)", "encyclopedia (6)" metaphors regarding each sub-theme. However, the explanations were found as diverse. For instance, while the human metaphor can be seen as quite frequent in the structural features of the technology theme, it can be found in the positive and negative effects of technology, and technology for the purpose of use sub-themes, as well.

Table 1. The metaphorical perceptions of prospective $2^{\text {nd }}$ grade-level teachers regarding technology

\begin{tabular}{|c|c|c|c|}
\hline Themes & Sub-themes & Metaphors & $\mathrm{f}$ \\
\hline \multirow{14}{*}{$\begin{array}{l}\text { Positive effects of } \\
\text { technology }\end{array}$} & $\begin{array}{l}\text { Having many different areas of } \\
\text { use }\end{array}$ & Level of development, puzzle, weapon, journal, ocean & 5 \\
\hline & Being beneficial & $\begin{array}{l}\text { Level of development, encyclopedia (2), information, rose, } \\
\text { game, tree }\end{array}$ & 7 \\
\hline & Enabling fast and easy access & $\begin{array}{l}\text { Having the brain sleep while it is still functioning, the world } \\
\text { (2), super power, source of life, source of information }\end{array}$ & 6 \\
\hline & $\begin{array}{l}\text { Providing an opportunity for } \\
\text { self-development }\end{array}$ & $\begin{array}{l}\text { Forest, curiosity, river, game (2), mirror, future, a relative } \\
\text { concept, iron, farm, well in a desert, renewal/development, } \\
\text { reading a book }\end{array}$ & 13 \\
\hline & $\begin{array}{l}\text { Directing to } \quad \text { make } \\
\text { research/discoveries }\end{array}$ & $\begin{array}{l}\text { World, curiosity, space, game (2), travel, ocean, endless } \\
\text { road, encyclopedia, a relative concept, a tool for } \\
\text { entertainment, a well in a desert, human, mathematics }\end{array}$ & 15 \\
\hline & $\begin{array}{l}\text { Taking part in every aspect of } \\
\text { life }\end{array}$ & $\begin{array}{l}\text { Journal, water, breath, mathematics (2), source of life, tree, } \\
\text { renewal/development }\end{array}$ & 8 \\
\hline & $\begin{array}{l}\text { Contributing to the rise of } \\
\text { civilization }\end{array}$ & Journal, information & 2 \\
\hline & $\begin{array}{l}\text { Supplying an idea about the } \\
\text { future }\end{array}$ & Future & 1 \\
\hline & $\begin{array}{l}\text { Enabling the discovery of the } \\
\text { universe }\end{array}$ & Construction machine & 1 \\
\hline & Promoting thinking & Construction machine & 1 \\
\hline & Saving time & A relative concept, experiment desk, source of life & 3 \\
\hline & $\begin{array}{l}\text { Paving the way for the source } \\
\text { of information }\end{array}$ & Book & 1 \\
\hline & Informing & School & 1 \\
\hline & Bringing innovations & Tree & 1 \\
\hline \multicolumn{3}{|l|}{ Sub-total } & 65 \\
\hline \multirow{8}{*}{$\begin{array}{l}\text { Negative effects of } \\
\text { technology }\end{array}$} & Inhibits thinking & Having the brain sleep while it is still functioning & 1 \\
\hline & Addictive & Black box, tree & 2 \\
\hline & Shuts down external stimuli & Black box, forest & 2 \\
\hline & Risks human life & Forest, iron, medicine, fire, human, life & 6 \\
\hline & Quick consumption & Songs, robot & 2 \\
\hline & Leads to becoming asocial & Life, school & 2 \\
\hline & Gets users to surf the Internet & A tool for entertainment & 1 \\
\hline & Leads to a waste of time & Rose, a tool for entertainment, human & 3 \\
\hline \multicolumn{3}{|l|}{ Sub-total } & 19 \\
\hline & $\begin{array}{l}\text { A conscious use (using in a } \\
\text { way that is correct/good/for the } \\
\text { benefit of humanity) }\end{array}$ & $\begin{array}{l}\text { Level of development, river, iron, farm, medicine, } \\
\text { encyclopedia, food, fire, both medicine, and poison }\end{array}$ & 9 \\
\hline
\end{tabular}




\begin{tabular}{|c|c|c|c|}
\hline \multirow[t]{7}{*}{$\begin{array}{l}\text { Technology by the } \\
\text { purpose of use }\end{array}$} & $\begin{array}{l}\text { Being both beneficial and } \\
\text { harmful }\end{array}$ & $\begin{array}{l}\text { Puzzle, forest, weapon, mirror, labyrinth, super power, a } \\
\text { relative concept, medicine, raising a child, human ( } 4) \text {, food, } \\
\text { fire, a tool for entertainment, rose, both medicine and } \\
\text { poison, sleep }\end{array}$ & 19 \\
\hline & Using it to waste time & Forest, mirror, a relative concept & 3 \\
\hline & Using it for entertainment & Forest & 1 \\
\hline & $\begin{array}{l}\text { Using it correctly and when } \\
\text { necessary }\end{array}$ & Eating, iron & 2 \\
\hline & Using it in teaching & Mathematics (2), encyclopedia, school & 4 \\
\hline & Importance of controlling it & Human, tree & 2 \\
\hline & Using it while doing research & Education & 1 \\
\hline \multicolumn{3}{|l|}{ Sub-total } & 41 \\
\hline \multirow{11}{*}{$\begin{array}{l}\text { The structural } \\
\text { features } \quad \text { of } \\
\text { technology }\end{array}$} & Being comprehensive & $\begin{array}{l}\text { World (2), space (2), game (2), tree, ocean, labyrinth, } \\
\text { encyclopedia, book, a source of knowledge, a tool for } \\
\text { entertainment, human, mathematics, reading a book, forest }\end{array}$ & 17 \\
\hline & Constantly developing & $\begin{array}{l}\text { Weapon, bacteria, brain, river, water, game, light, future, } \\
\text { beam, big bang, breath, songs, ocean, robot, endless road, } \\
\text { tree, life (2), mathematics (2), farm, information, news } \\
\text { portal, human (6), change, humanity }\end{array}$ & 31 \\
\hline & Being dynamic and changing & $\begin{array}{l}\text { Weapon, bacteria, river, light, beam, human (5), life (2), } \\
\text { information, news portal, mathematics, change }\end{array}$ & 16 \\
\hline & Rapid spread/dissemination & Bacteria & 1 \\
\hline & Pushing the limits of the mind & Space & 1 \\
\hline & Progressing & Breath, mathematics, human (3), change, humanity & 7 \\
\hline & Involving algorithms & Mathematics (2) & 2 \\
\hline & Being complex & Labyrinth & 1 \\
\hline & Being endless & Endless road, beam & 2 \\
\hline & Being systematic & Space, system & 2 \\
\hline & $\begin{array}{l}\text { Something produced by } \\
\text { humans }\end{array}$ & Human & 1 \\
\hline \multicolumn{3}{|l|}{ Sub-total } & 81 \\
\hline \multirow{12}{*}{$\begin{array}{l}\text { The contributions of } \\
\text { technology to the } \\
\text { student }\end{array}$} & Enabling active learning & Curiosity, experiment lab, news portal & 3 \\
\hline & $\begin{array}{l}\text { Enabling a better } \\
\text { learning/conceptualization }\end{array}$ & Game, mathematics, eraser & 3 \\
\hline & $\begin{array}{l}\text { Compensating for the missed } \\
\text { subjects }\end{array}$ & Education & 1 \\
\hline & $\begin{array}{l}\text { Enabling the realization of the } \\
\text { mistakes while solving } \\
\text { problems }\end{array}$ & Education & 1 \\
\hline & Enabling learning by enjoying & A relative concept, experiment desk, game & 3 \\
\hline & $\begin{array}{l}\text { Ensuring the elimination of } \\
\text { misconceptions }\end{array}$ & A relative concept, eraser, teaching material & 3 \\
\hline & Drawing attention to the course & Experiment lab, news portal & 2 \\
\hline & $\begin{array}{l}\text { Preventing the formation of } \\
\text { misconceptions }\end{array}$ & Experiment lab & 1 \\
\hline & Enabling permanent learning & News portal & 1 \\
\hline & Enabling concretization & News portal & 1 \\
\hline & Enabling visualization & Teaching material & 1 \\
\hline & $\begin{array}{l}\text { Effecting academic } \\
\text { achievement }\end{array}$ & School & 1 \\
\hline \multicolumn{3}{|l|}{ Sub-total } & 21 \\
\hline \multirow{4}{*}{$\begin{array}{l}\text { The contributions of } \\
\text { technology to the } \\
\text { teacher }\end{array}$} & $\begin{array}{l}\text { Providing convenience in } \\
\text { teaching subjects }\end{array}$ & Curiosity, news portal, source of knowledge & 3 \\
\hline & $\begin{array}{l}\text { Providing the opportunity to } \\
\text { teach with visual and auditory } \\
\text { stimuli }\end{array}$ & Brain & 1 \\
\hline & $\begin{array}{l}\text { Existence of many programs } \\
\text { that can be used in } \\
\text { mathematics teaching }\end{array}$ & Eraser & 1 \\
\hline & $\begin{array}{l}\text { Preventing the course from } \\
\text { being monotonous }\end{array}$ & Experiment desk & 1 \\
\hline \multicolumn{3}{|l|}{ Sub-total } & 6 \\
\hline & Being necessary & $\begin{array}{l}\text { Eating, water, source of life, tree, an addictive substance, a } \\
\text { well in desert }\end{array}$ & 6 \\
\hline
\end{tabular}




\begin{tabular}{|c|c|c|c|}
\hline \multirow{7}{*}{$\begin{array}{l}\text { Developing a } \\
\text { positive attitude } \\
\text { towards technology }\end{array}$} & $\begin{array}{l}\text { Occupying an important place } \\
\text { in education }\end{array}$ & Eating & 1 \\
\hline & $\begin{array}{l}\text { Advanced technology's being } \\
\text { fascinating }\end{array}$ & Space & 1 \\
\hline & Being happy as you learn & Endless road & 1 \\
\hline & Being hopeful for the future & Life & 1 \\
\hline & Enjoying spending time & Mother, mathematics & 2 \\
\hline & $\begin{array}{l}\text { Feeling the need to follow the } \\
\text { latest technologies }\end{array}$ & Farm & 1 \\
\hline & Need to spend effort to learn & A well in a desert & 1 \\
\hline \multicolumn{3}{|l|}{ Sub-total } & 14 \\
\hline $\begin{array}{c}\text { Developing negative } \\
\text { attitude towards } \\
\text { technology }\end{array}$ & $\begin{array}{l}\text { The idea that technology will } \\
\text { vanish one day }\end{array}$ & Human & 1 \\
\hline \multicolumn{3}{|l|}{ Sub-total } & 1 \\
\hline \multicolumn{3}{|l|}{ Total } & 248 \\
\hline
\end{tabular}

When Table 1 is examined it is obvious that the prospective teachers produced more metaphors for "the structural features of technology" and "positive effects of technology" themes. The sub-themes in which the highest number of metaphors were produced was found according to their structural features as constantly developing, being comprehensive, being dynamic and changing, being progressive; according to their purposes of use as both beneficial and harmful, and conscious use; in terms of positive effects as directing to make research/discoveries, giving an opportunity for self-development, being in every aspect of our lives, having diverse areas of use, being beneficial, and enabling fast and easy access; in terms of negative effects as risking human life; in terms of developing a positive attitude as being necessary. Examples for these are presented below.

Table 2. The sub-themes and metaphor explanations related to the positive effects of technology theme in prospective $2^{\text {nd }}$ grade teachers

\begin{tabular}{|c|c|c|}
\hline Sub-themes & Metaphor & Explanations \\
\hline $\begin{array}{l}\text { Providing an } \\
\text { opportunity for self- } \\
\text { development }\end{array}$ & Game & 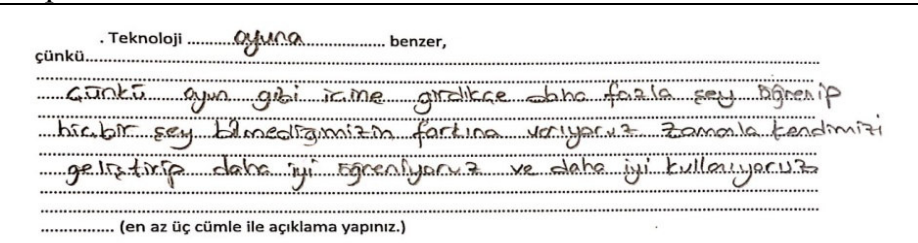 \\
\hline $\begin{array}{l}\text { Directing to make } \\
\text { research/discoveries }\end{array}$ & Travel & 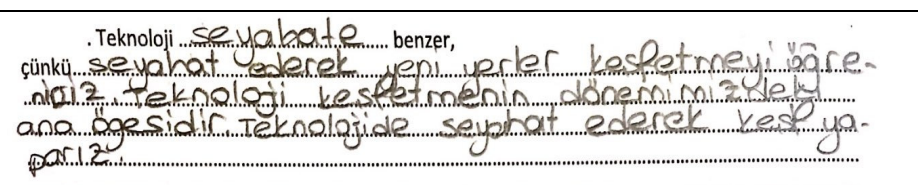 \\
\hline $\begin{array}{l}\text { Taking part in every } \\
\text { aspect of life }\end{array}$ & Mathematics & 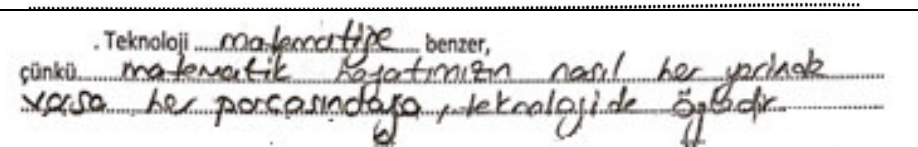 \\
\hline Being beneficial & Game & 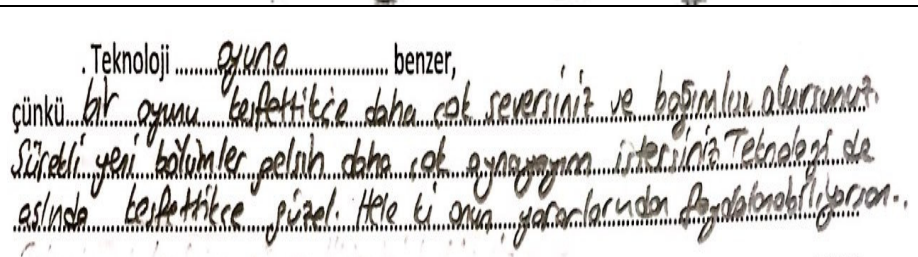 \\
\hline $\begin{array}{l}\text { Having many } \\
\text { different areas of use }\end{array}$ & Ocean & 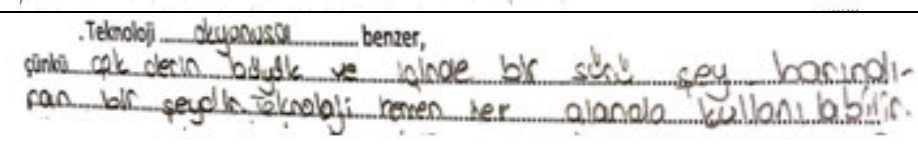 \\
\hline $\begin{array}{l}\text { Enabling fast and } \\
\text { easy access }\end{array}$ & World & 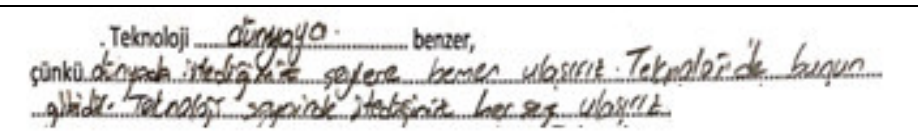 \\
\hline
\end{tabular}


Table 3. The sub-themes and metaphor explanations related to the negative effects of the technology theme in prospective $2^{\text {nd }}$ grade teachers

\begin{tabular}{|c|c|c|}
\hline Sub-themes & Metaphor & Explanations \\
\hline Risks human life & Iron & 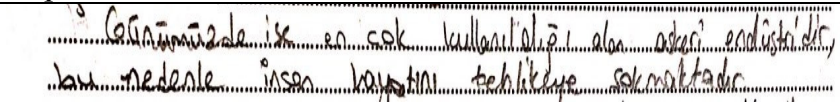 \\
\hline
\end{tabular}

Table 4. The sub-themes and metaphor explanations related to technology's areas of use theme in prospective $2^{\text {nd }}$ grade teachers

\begin{tabular}{|c|c|c|}
\hline Sub-themes & Metaphor & Explanations \\
\hline $\begin{array}{l}\text { Being } \\
\text { beneficial } \\
\text { harmful }\end{array}$ & Food & 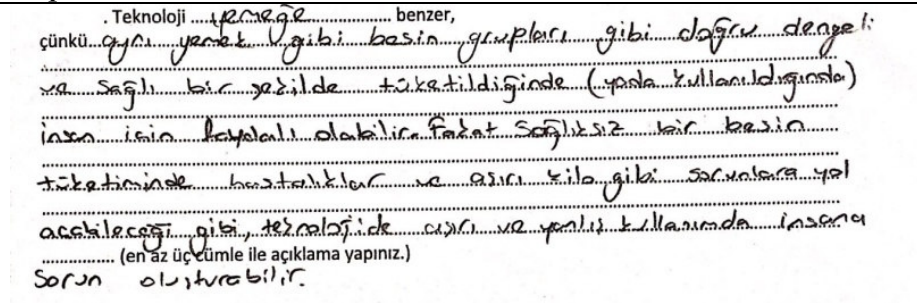 \\
\hline \multirow[t]{2}{*}{$\begin{array}{l}\text { A conscious use } \\
\text { (using in a way that } \\
\text { is correct/good/for } \\
\text { the benefit of } \\
\text { humanity) }\end{array}$} & Iron & 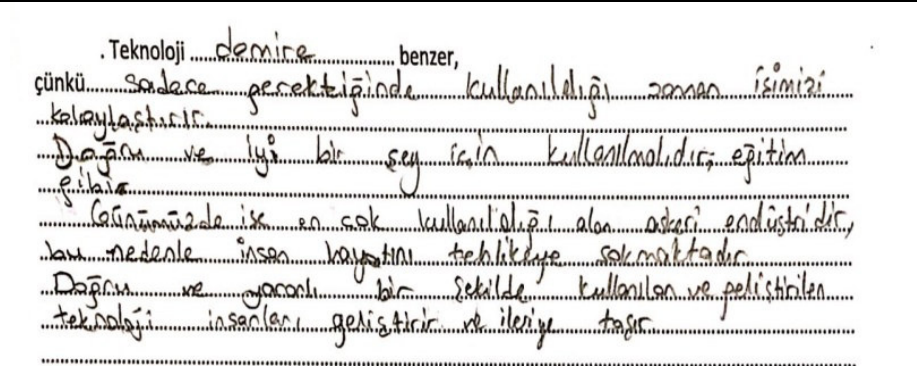 \\
\hline & Farm & 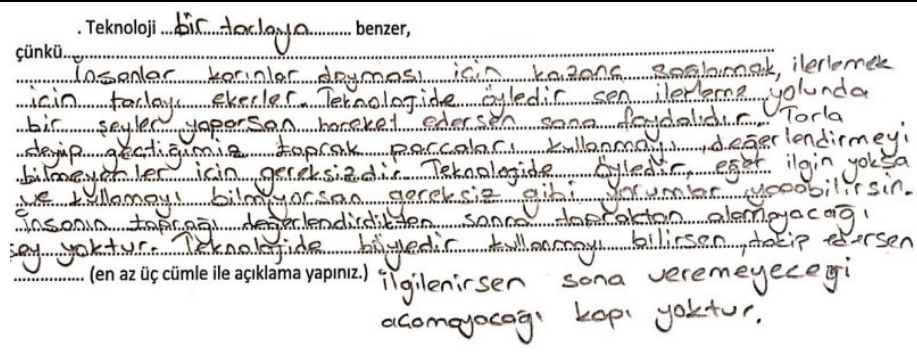 \\
\hline
\end{tabular}

Table 5. The sub-themes and metaphor explanations related to the structural features of technology theme in prospective $2^{\text {nd }}$ grade teachers

\begin{tabular}{|c|c|c|}
\hline Sub-themes & Metaphor & Explanations \\
\hline $\begin{array}{l}\text { Being } \\
\text { comprehensive }\end{array}$ & Encyclopedia & 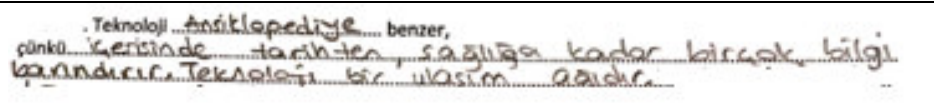 \\
\hline $\begin{array}{l}\text { Constantly } \\
\text { developing }\end{array}$ & Information & 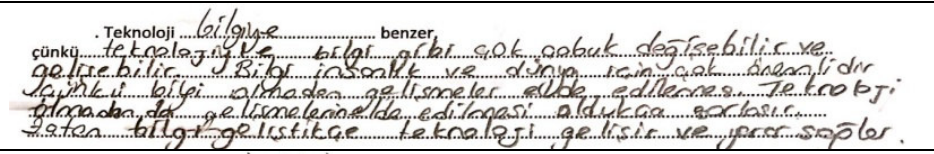 \\
\hline $\begin{array}{l}\text { Being dynamic } \\
\text { and changing }\end{array}$ & Change & 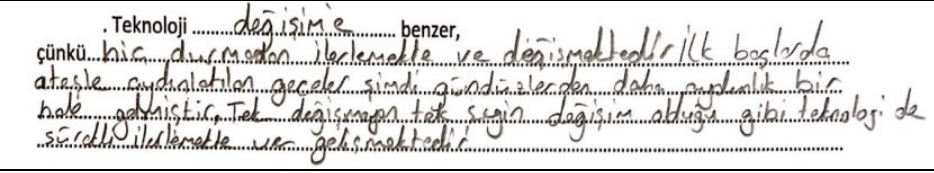 \\
\hline Progressing & humanity & 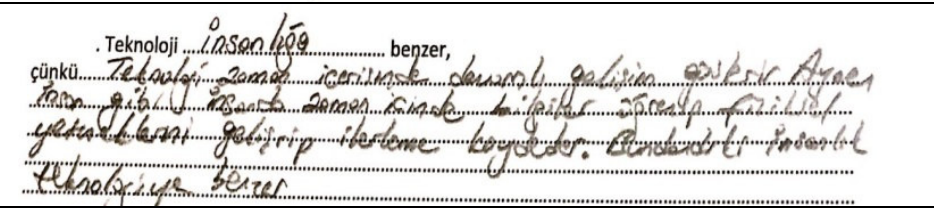 \\
\hline
\end{tabular}


Table 6. The sub-themes and metaphor explanations related to developing a positive attitude towards technology in prospective $2^{\text {nd }}$ grade teachers

\begin{tabular}{|c|c|c|}
\hline Sub-themes & Metaphor & Explanations \\
\hline Being necessary & Water & 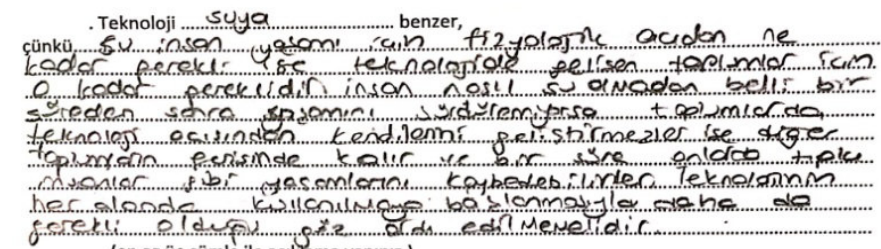 \\
\hline
\end{tabular}

Twenty-one metaphors within 12 sub-themes were produced regarding the contributions of technology to the student. It was revealed that the prospective teachers more frequently mentioned the contributions of technology in terms of ensuring a better learning/conceptualization, enabling learning by enjoying, and ensuring the elimination of misconceptions. In this respect, it is safe to claim that the awareness of the prospective teachers was raised regarding the contributions of technology to their own learning experiences. The contributions of technology from the perspective of teachers were mostly regarded in terms of providing convenience in teaching. The explanations of prospective teachers were presented as examples for this situation. One of the prospective teachers speculated that technology will vanish one day. When it is considered that today is the age of technology, this is quite interesting. The participant's explanation is as follows:

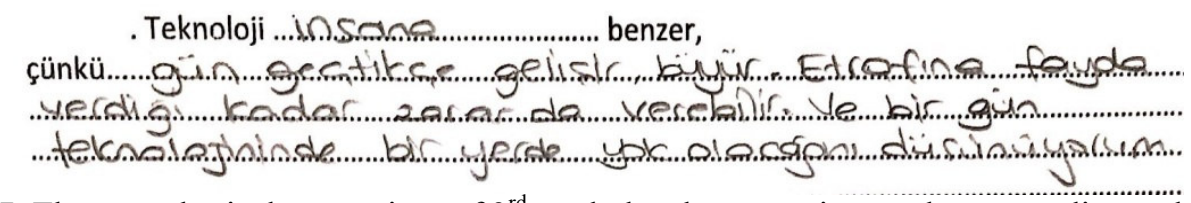

Table 7. The metaphorical perceptions of $3^{\text {rd }}$ grade-level prospective teachers regarding technology

\begin{tabular}{|c|c|c|c|}
\hline Themes & Sub-themes & Metaphors & $\mathrm{f}$ \\
\hline \multirow{18}{*}{$\begin{array}{l}\text { Positive effects of } \\
\text { technology }\end{array}$} & $\begin{array}{l}\text { Having many different areas } \\
\text { of use/being useful }\end{array}$ & Right arm, space, toy & 3 \\
\hline & Being beneficial & $\begin{array}{l}\text { Kite, information, support team, right arm, a new age, soil, } \\
\text { sapling }\end{array}$ & 7 \\
\hline & Enabling fast and easy access & Friend(2), water, life & 4 \\
\hline & $\begin{array}{l}\text { Providing an opportunity for } \\
\text { self-development }\end{array}$ & Bottomless well, life, time, universe, humanity, sapling & 6 \\
\hline & Making life easier & Mathematics, science, life, car, universe, light & 6 \\
\hline & $\begin{array}{l}\text { Directing how to do research } \\
\text { and make discoveries }\end{array}$ & An endless ocean, bottomless well, brain & 3 \\
\hline & $\begin{array}{l}\text { Being in every aspect of our } \\
\text { lives }\end{array}$ & $\begin{array}{l}\text { A course conducted with a computer program, mathematics, } \\
\text { life, universe, tree }\end{array}$ & 5 \\
\hline & $\begin{array}{l}\text { Contributing to the rise of } \\
\text { civilization }\end{array}$ & Water & 1 \\
\hline & Saving time & Car & 1 \\
\hline & New information & Rain & 1 \\
\hline & Developing teaching & Blood, right arm & 2 \\
\hline & $\begin{array}{l}\text { Enabling users to overcome } \\
\text { problems }\end{array}$ & Mathematics, space & 2 \\
\hline & Yielding financial gain & Mathematics & 1 \\
\hline & $\begin{array}{l}\text { Enabling achievement of the } \\
\text { goal }\end{array}$ & Car & 1 \\
\hline & Enlightening & Light & 1 \\
\hline & $\begin{array}{l}\text { Enabling the development of } \\
\text { a perspective }\end{array}$ & Humanity & 1 \\
\hline & Spurring innovation & Rain, light & 2 \\
\hline & Being interesting & Toy & 1 \\
\hline \multicolumn{3}{|l|}{ Sub-total } & 48 \\
\hline \multirow{2}{*}{$\begin{array}{c}\text { Negative effects of } \\
\text { technology }\end{array}$} & Addiction & Friend & 1 \\
\hline & Risking human life & Weapon & 1 \\
\hline \multicolumn{3}{|l|}{ Sub-total } & 2 \\
\hline & $\begin{array}{l}\text { Conscious use } \\
\text { (correct/good/for the benefit } \\
\text { of humanity) }\end{array}$ & Weapon, a magic box & 2 \\
\hline
\end{tabular}




\begin{tabular}{|c|c|c|c|}
\hline \multirow[t]{4}{*}{$\begin{array}{l}\text { Technology by the } \\
\text { purpose of use }\end{array}$} & $\begin{array}{l}\text { Being both beneficial and } \\
\text { harmful }\end{array}$ & $\begin{array}{l}\text { Weapon, magic box, desert, ocean, sea, tool, real numbers, } \\
\text { book, }\end{array}$ & 9 \\
\hline & $\begin{array}{l}\text { Using for entertainment } \\
\text { purposes }\end{array}$ & Car & 1 \\
\hline & Using in teaching & Water, people's desires, blood, friend, a new age & 5 \\
\hline & Importance of controlling it & Snowball, life, magic box, kite, book & 5 \\
\hline \multicolumn{3}{|r|}{ 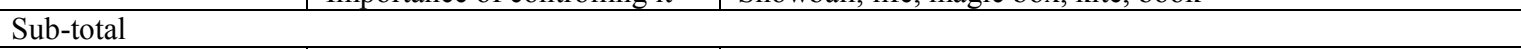 } & 22 \\
\hline \multirow{10}{*}{$\begin{array}{l}\text { The structural } \\
\text { features of } \\
\text { technology }\end{array}$} & Being comprehensive & $\begin{array}{l}\text { Life, endless ocean, magic box, limit, bottomless well, } \\
\text { brain(2), ocean, real numbers, the branches of a tree, sea }\end{array}$ & 11 \\
\hline & Constantly developing & $\begin{array}{l}\text { Snowball, endless ocean, time machine, limit, people's } \\
\text { desires, a course to be conducted with a computer program, } \\
\text { time (2), science, human (2), brain, real numbers, space, toy, } \\
\text { universe, light, humanity, sapling, tree }\end{array}$ & 20 \\
\hline & Being dynamic and changing & $\begin{array}{l}\text { Snowball, people's desires, a course to be conducted with a } \\
\text { computer program, time (2), science, human (2), brain, space, } \\
\text { toy, humanity, tree }\end{array}$ & 13 \\
\hline & Quick spread/dissemination & Snowball, a course to be conducted with a computer program & 2 \\
\hline & Progressing & Time, science, human, light & 4 \\
\hline & Being complex & Brain, human & 2 \\
\hline & Being endless & Limit, bottomless well, brain, real numbers & 4 \\
\hline & Being systematic & Brain & 1 \\
\hline & Not being relative & Science & 1 \\
\hline & Requirement of skill to use it & Toy & 1 \\
\hline \multicolumn{3}{|l|}{ Sub-total } & 59 \\
\hline \multirow{6}{*}{$\begin{array}{c}\text { The contributions of } \\
\text { technology to the } \\
\text { student }\end{array}$} & Enabling active learning & Enjoyable teaching, a new age & 2 \\
\hline & $\begin{array}{l}\text { Compensating for missed } \\
\text { subjects }\end{array}$ & Blood & 1 \\
\hline & $\begin{array}{l}\text { Enabling learning by } \\
\text { enjoying }\end{array}$ & Life, enjoyable teaching, support team & 3 \\
\hline & Enabling easy learning & Life, support team & 2 \\
\hline & $\begin{array}{l}\text { Keeping/Maintaining the } \\
\text { student's interest in the } \\
\text { course }\end{array}$ & Right arm & 1 \\
\hline & Enabling permanent learning & Life (2), people's desires, riding a bike & 4 \\
\hline \multicolumn{3}{|l|}{ Sub-total } & 13 \\
\hline $\begin{array}{l}\text { The contributions of } \\
\text { technology to the } \\
\text { teacher }\end{array}$ & $\begin{array}{l}\text { The effective use of the } \\
\text { teacher }\end{array}$ & Blood & 1 \\
\hline \multicolumn{3}{|l|}{ Sub-total } & 1 \\
\hline \multirow{6}{*}{$\begin{array}{l}\text { Developing a positive } \\
\text { attitude towards } \\
\text { technology }\end{array}$} & Being necessary & Rain, water, life & 3 \\
\hline & Enjoying spending time & Enjoyable teaching, mathematics, car, riding a bike, sea & 5 \\
\hline & $\begin{array}{l}\text { Feeling the need to follow the } \\
\text { latest technologies }\end{array}$ & Time & 1 \\
\hline & $\begin{array}{l}\text { Having the idea that learning } \\
\text { is inevitable }\end{array}$ & $\begin{array}{l}\text { Endless ocean, people's desires, information, time, soil, } \\
\text { sapling, tree, sea }\end{array}$ & 8 \\
\hline & $\begin{array}{l}\text { The need to spend effort for } \\
\text { learning }\end{array}$ & Kite & 1 \\
\hline & Love & Friend & 1 \\
\hline \multicolumn{3}{|l|}{ Sub-total } & 19 \\
\hline \multirow{3}{*}{$\begin{array}{l}\text { Developing negative } \\
\text { attitude towards } \\
\text { technology }\end{array}$} & $\begin{array}{l}\text { The feeling of being } \\
\text { unsuccessful }\end{array}$ & Bottomless well, riding a bike & 2 \\
\hline & $\begin{array}{l}\text { Being boring for the one who } \\
\text { doesn't know }\end{array}$ & Mathematics & 1 \\
\hline & $\begin{array}{l}\text { Thinking that it is not that } \\
\text { necessary }\end{array}$ & Support team & 1 \\
\hline \multicolumn{3}{|l|}{ Sub-total } & 4 \\
\hline \multicolumn{3}{|l|}{ Total } & \\
\hline
\end{tabular}

When Table 7 is examined it can be determined that the prospective teachers produced more metaphors under the themes of "the structural features of technology" and "the positive effects of technology". Even if the themes are the same, interestingly enough, the sub-themes can be different. At this point, it can be claimed that the prospective third-grade teachers diversified the positive effects of technology themes with their different views, and approached from different perspectives. The sub-themes where the highest number of metaphors were produced are in terms of positive effects, being beneficial, providing an opportunity for self-development, 
making life easier, being present in every aspect of life; in terms of purposes of use, being both beneficial and harmful, using in education, importance of controlling it; in terms of structural features, being comprehensive, being constantly developing, being dynamic and changing; in terms of positive attitude development, enjoying spending time, feeling the need for following the daily developments, thinking that learning is inevitable. The explanations of prospective teachers are presented as an example for this situation.

Table 8. The sub-themes and metaphor explanations related to the positive effects of technology theme in prospective $3^{\text {rd }}$ grade teachers

\begin{tabular}{|c|c|c|}
\hline & \multirow{3}{*}{$\begin{array}{l}\text { Metaphor } \\
\text { Sapling }\end{array}$} & \multirow[b]{2}{*}{ Explanations } \\
\hline & & \\
\hline Being beneficial & & 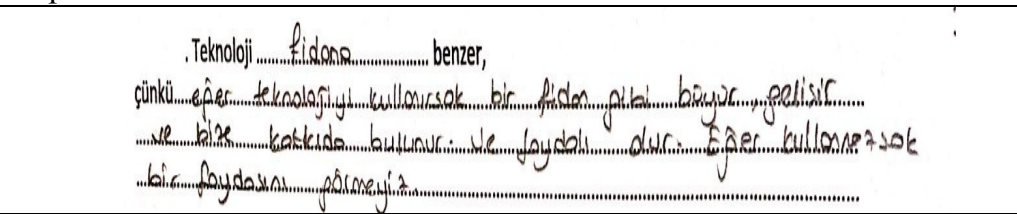 \\
\hline & Soil & 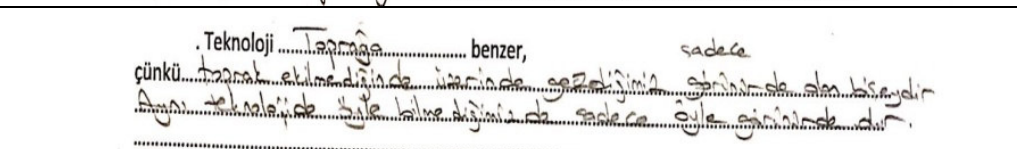 \\
\hline & & 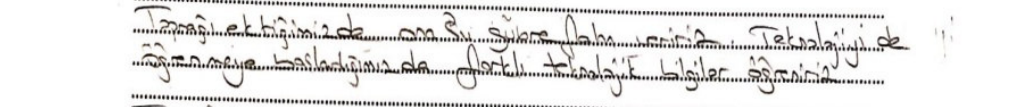 \\
\hline & & 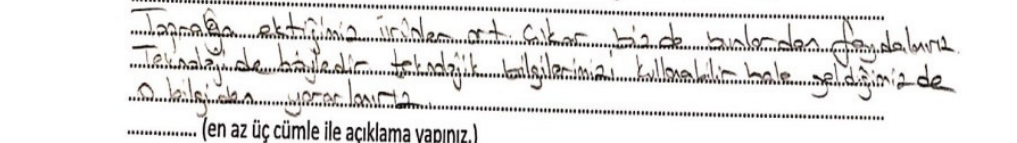 \\
\hline $\begin{array}{l}\text { Providing an } \\
\text { opportunity for } \\
\text { self-development }\end{array}$ & Humanity & 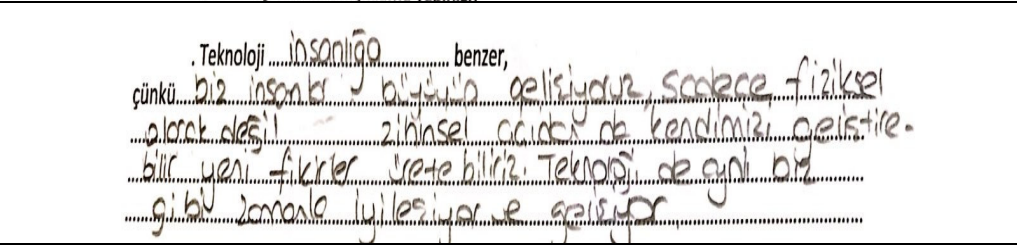 \\
\hline Making life easier & Light & 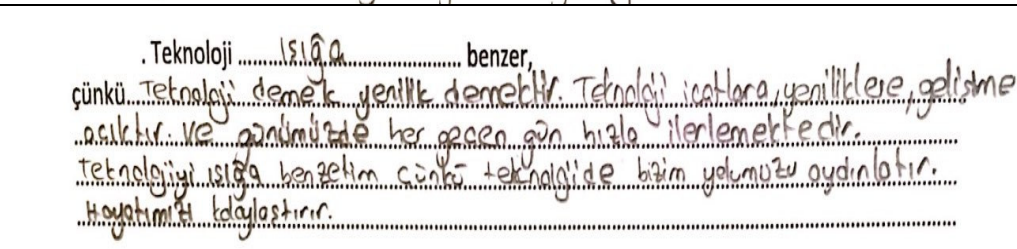 \\
\hline $\begin{array}{l}\text { Being in every } \\
\text { aspect of our lives }\end{array}$ & Tree & 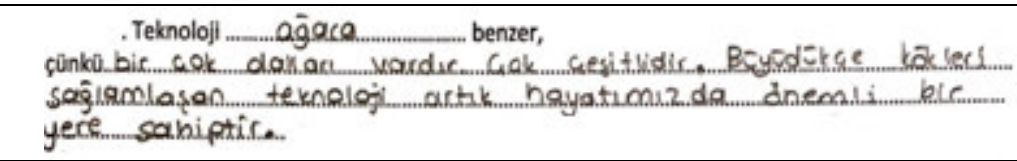 \\
\hline
\end{tabular}


Table 9. The sub-themes and metaphor explanations related to technology's purposes of use theme in prospective $3^{\text {rd }}$ grade teachers

\begin{tabular}{|c|c|c|}
\hline Sub-themes & Metaphor & Explanations \\
\hline \multirow[t]{2}{*}{$\begin{array}{lr}\text { Being } & \text { both } \\
\text { beneficial } & \text { and } \\
\text { harmful } & \end{array}$} & Magic box & 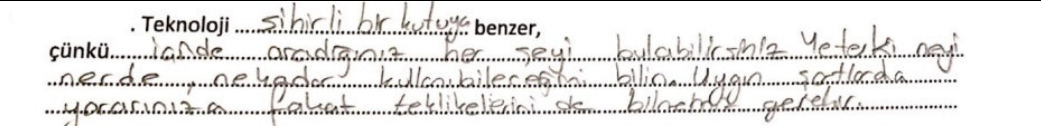 \\
\hline & Sea & 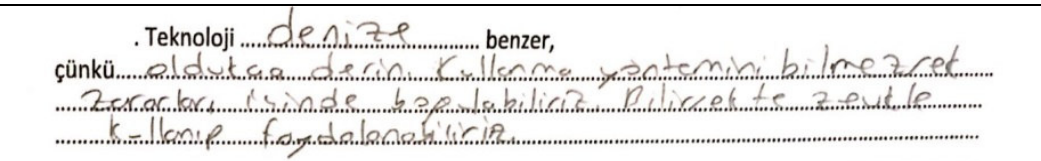 \\
\hline $\begin{array}{ll}\text { Using } & \text { in } \\
\text { teaching } & \end{array}$ & Water & 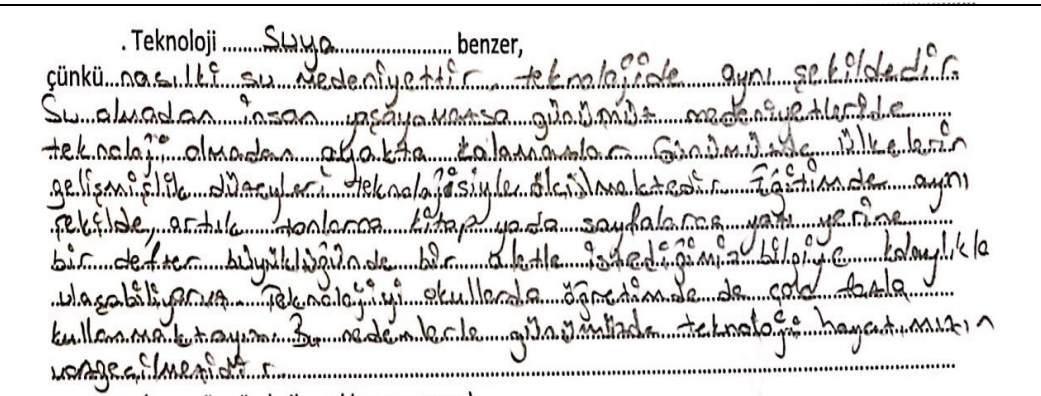 \\
\hline \multirow[t]{2}{*}{$\begin{array}{l}\text { Importance of } \\
\text { controlling }\end{array}$} & Snowball & 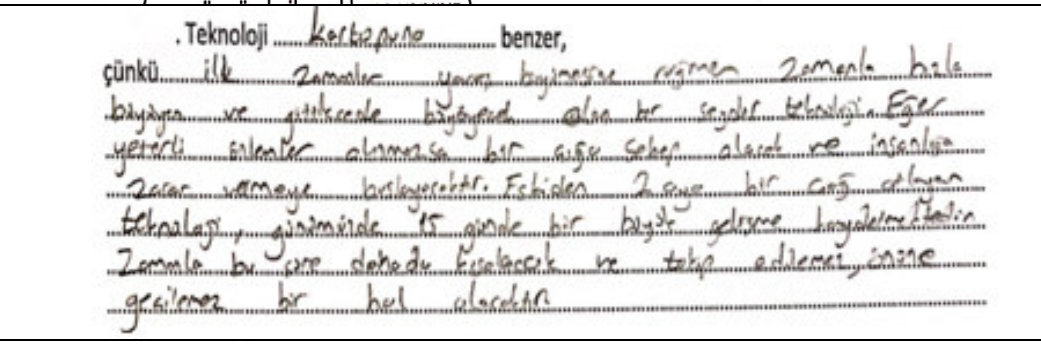 \\
\hline & Kite & 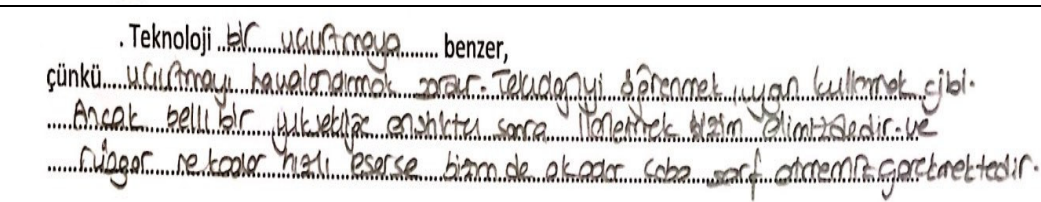 \\
\hline
\end{tabular}

Table 10. The sub-themes and metaphor explanations related to the structural features of technology theme in prospective $3^{\text {rd }}$ grade teachers

\begin{tabular}{|c|c|c|}
\hline Sub-themes & Metaphor & Explanations \\
\hline $\begin{array}{l}\text { Being } \\
\text { comprehensive }\end{array}$ & Sea & 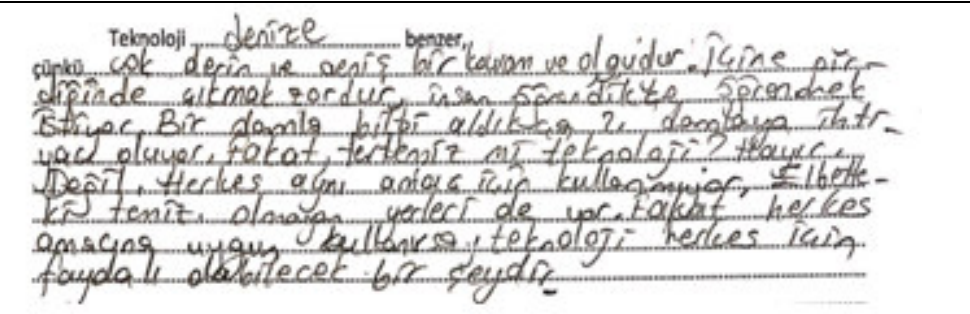 \\
\hline $\begin{array}{l}\text { Constantly } \\
\text { developing }\end{array}$ & Toy & 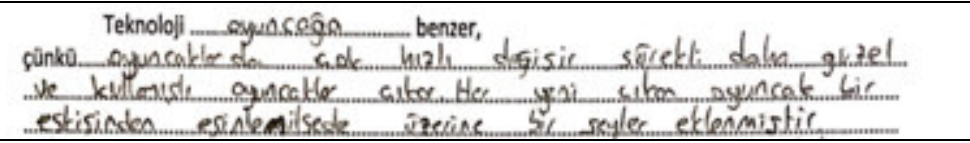 \\
\hline $\begin{array}{l}\text { Being dynamic and } \\
\text { changing }\end{array}$ & Time & 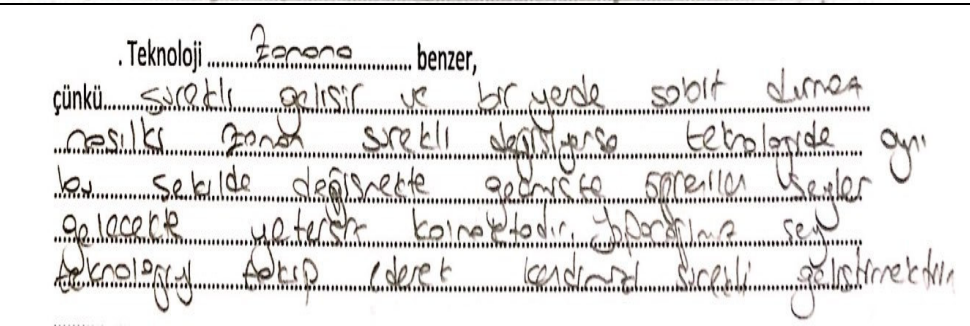 \\
\hline
\end{tabular}


Table 11. The sub-themes and metaphor explanations related to developing a positive attitude towards technology theme in prospective $3^{\text {rd }}$ grade teachers

\begin{tabular}{|c|c|c|}
\hline Sub-themes & Metaphor & Explanations \\
\hline $\begin{array}{l}\text { Enjoying spending } \\
\text { time }\end{array}$ & $\begin{array}{l}\text { Riding a } \\
\text { bike }\end{array}$ & 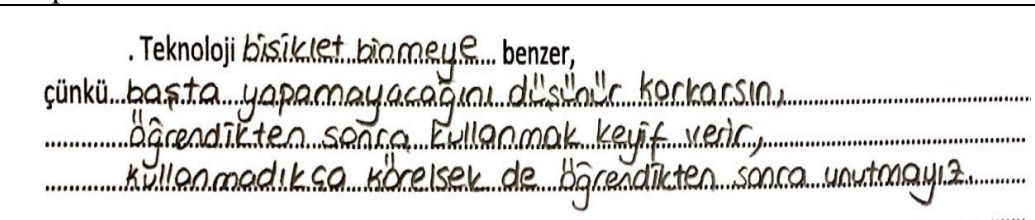 \\
\hline $\begin{array}{l}\text { Having the idea that } \\
\text { learning is inevitable }\end{array}$ & $\begin{array}{l}\text { Endless } \\
\text { ocean }\end{array}$ & 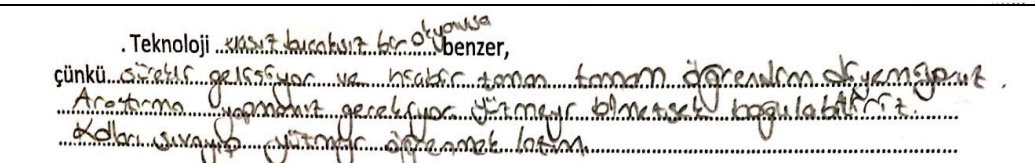 \\
\hline
\end{tabular}

Table 12. The metaphorical perceptions of prospective $4^{\text {th }}$ grade-level teachers regarding technology

\begin{tabular}{|c|c|c|c|}
\hline Themes & Sub-themes & Metaphors & $\mathrm{f}$ \\
\hline \multirow{22}{*}{$\begin{array}{l}\text { Positive effects of } \\
\text { technology }\end{array}$} & $\begin{array}{l}\text { Having many different } \\
\text { areas of use/being useful }\end{array}$ & Potato, tractor, sun, water, wheel, revolution & 6 \\
\hline & $\begin{array}{ll}\text { Conscious } & \text { use } \\
\text { (correct/good/ for the } \\
\text { benefit of humanity) }\end{array}$ & $\begin{array}{l}\text { Enzyme, sharp/penetrating/inflammatory materials, } \\
\text { snowball, traffic signs, wheel }\end{array}$ & 5 \\
\hline & Being beneficial & Potato, mother, tree, ladder, human, sun & 6 \\
\hline & $\begin{array}{l}\text { Enabling fast and easy } \\
\text { access }\end{array}$ & $\begin{array}{l}\text { Mother (2), magic lamp, eye glasses, assisting } \\
\text { referee, fire, plane }\end{array}$ & 7 \\
\hline & $\begin{array}{l}\text { Providing an opportunity } \\
\text { for self-development }\end{array}$ & $\begin{array}{l}\text { Wearing makeup, tree (2), eye glasses, human, fire, } \\
\text { heart }\end{array}$ & 7 \\
\hline & Making life easier & $\begin{array}{llr}\begin{array}{l}\text { Mother, enzyme, } \\
\text { sharp/penetrating/inflammatory } \\
\text { traffic signs, plane }\end{array} & \begin{array}{l}\text { space, } \\
\text { materials, }\end{array} & \text { fire, } \\
\text { brain, }\end{array}$ & 8 \\
\hline & $\begin{array}{l}\text { Being present in every } \\
\text { aspect of life }\end{array}$ & Chameleon, tree, ocean & 4 \\
\hline & $\begin{array}{l}\text { Contribution to the rise } \\
\text { of civilization }\end{array}$ & Ladder, fire, water & 3 \\
\hline & Bringing innovations & Space, revolution & 2 \\
\hline & $\begin{array}{l}\text { Directing to do research } \\
\text { and make discoveries }\end{array}$ & Space & 1 \\
\hline & Saving time & Mother (2), ladder, tractor & 4 \\
\hline & $\begin{array}{ll}\begin{array}{l}\text { Enabling learning by } \\
\text { enjoying }\end{array} & \\
\end{array}$ & Mother & 1 \\
\hline & $\begin{array}{l}\text { Enabling to overcome } \\
\text { the problems }\end{array}$ & Human & 1 \\
\hline & Supporting teaching & Mother & 1 \\
\hline & $\begin{array}{l}\text { Enabling development of } \\
\text { the point of view }\end{array}$ & Ladder & 1 \\
\hline & Decreasing the workload & Mother (2), tractor, plane, assisting referee & 5 \\
\hline & Enhancing self-efficacy & Wearing makeup & 1 \\
\hline & Providing feedback & Mother & 1 \\
\hline & Virtual reality & Magic lamp & 1 \\
\hline & $\begin{array}{l}\text { Being helpful in decision } \\
\text { making }\end{array}$ & Assisting referee & 1 \\
\hline & $\begin{array}{l}\text { Enhancing the quality of } \\
\text { education }\end{array}$ & A table's legs & 1 \\
\hline & $\begin{array}{lr}\text { Making } & \text { digital } \\
\text { information } & \text { sharing } \\
\text { possible } & \\
\end{array}$ & Tree & 1 \\
\hline \multicolumn{3}{|l|}{ Sub-total } & 68 \\
\hline \multirow{2}{*}{$\begin{array}{l}\text { Negative effects of } \\
\text { technology }\end{array}$} & Cyber bullying & Iceberg & 1 \\
\hline & Risking human life & Space (2), sharp/penetrating, inflammatory materials & 3 \\
\hline
\end{tabular}




\begin{tabular}{|c|c|c|c|}
\hline Sub-total & & & 4 \\
\hline $\begin{array}{l}\text { Technology by the } \\
\text { purposes of use }\end{array}$ & $\begin{array}{l}\text { Being both beneficial } \\
\text { and harmful }\end{array}$ & $\begin{array}{l}\text { Potato, wearing makeup, coffee, tractor, fire (2), } \\
\text { sharp/penetrating/inflammatory materials, snowball, } \\
\text { traffic signs, wheel }\end{array}$ & 10 \\
\hline & Using in teaching & Chameleon, eye glasses, a table's legs & 3 \\
\hline & $\begin{array}{l}\text { Importance of } \\
\text { controlling it }\end{array}$ & Tractor, enzyme, cancer, fire & 4 \\
\hline Sub-total & & & 17 \\
\hline & Being comprehensive & $\begin{array}{l}\text { Space (2), ocean, fire, sapling, water, iceberg, } \\
\text { revolution }\end{array}$ & 8 \\
\hline & $\begin{array}{ll}\text { Being } & \text { constantly } \\
\text { developing }\end{array}$ & $\begin{array}{l}\text { Chameleon, space (3), ladder, human (2), time, tree, } \\
\text { sun, brain, snowball, cancer, sapling, stainless steel }\end{array}$ & 15 \\
\hline Structural features of & $\begin{array}{l}\text { Being dynamic and } \\
\text { changing }\end{array}$ & Chameleon, sun, cancer, sapling & 4 \\
\hline technology & Being progressive & Human, space, tree & 3 \\
\hline & Being complicated & Brain & 1 \\
\hline & Being infinitive & Space (3), sapling & 4 \\
\hline & Being rapidly developing & Time & 1 \\
\hline & Being long-lasting & Stainless iron & 1 \\
\hline & Requiring skills to use & Coffee, seed & 2 \\
\hline & $\begin{array}{l}\text { Teacher's need of } \\
\text { knowledge and skill to } \\
\text { use in education }\end{array}$ & A table's legs & 1 \\
\hline Sub-total & & & 40 \\
\hline The contributions of & Enabling active learning & Mother & 1 \\
\hline technology to student & $\begin{array}{l}\text { Compensating for the } \\
\text { missing subjects }\end{array}$ & Mother & 1 \\
\hline Sub-total & & & 2 \\
\hline $\begin{array}{l}\text { Developing a positive } \\
\text { attitude towards }\end{array}$ & Being necessary & $\begin{array}{l}\text { Tree, enzyme, space, sun, cancer, water, traffic signs, } \\
\text { heart }\end{array}$ & 8 \\
\hline technology & $\begin{array}{l}\text { Having the idea that } \\
\text { learning is inevitable }\end{array}$ & $\begin{array}{l}\text { Wearing makeup, tree, seed, ocean, brain, iceberg, } \\
\text { heart }\end{array}$ & 7 \\
\hline Sub-total & & & 15 \\
\hline $\begin{array}{c}\text { Developing negative } \\
\text { attitude towards } \\
\text { technology }\end{array}$ & $\begin{array}{l}\text { Being an uncontrolled } \\
\text { power }\end{array}$ & Ladder, assisting referee, ocean, time, snowball & 5 \\
\hline Sub-total & & & 5 \\
\hline Total & & & 151 \\
\hline
\end{tabular}

It is obvious in Table 12 that as in other grade levels the prospective fourth-grade teachers also revealed a higher number of metaphors in "the structural features of technology", and "the positive effects of technology" themes. It can be seen that even if the themes are the same, the sub-themes showed differences. At this point, it can be determined that the prospective third-grade teachers diversified the positive effects of technology themes with their views, and they approached them from different perspectives. The sub-themes in which more metaphors were produced are in terms of positive effects making life easier, providing fast and easy access, providing an opportunity for self-development, having many different areas of use; in terms of the purposes of use being both beneficial and harmful, in terms of structural features, being comprehensive, and constantly developing; in terms of developing a positive attitudes being necessary, having the idea that learning is inevitable; in terms of developing negative attitude, being an uncontrolled power. The explanations of prospective teachers were provided as an example for these situations. 
Table 13. The sub-themes and metaphor explanations related to the positive effects of technology theme in prospective $4^{\text {th }}$ grade teachers

\begin{tabular}{|c|c|c|}
\hline Sub-themes & Metaphor & Explanations \\
\hline \multirow[t]{2}{*}{$\begin{array}{l}\text { Making life } \\
\text { easier }\end{array}$} & Enzyme & 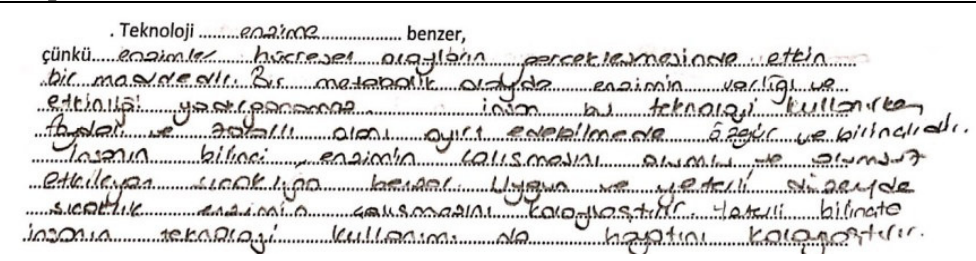 \\
\hline & Fire & 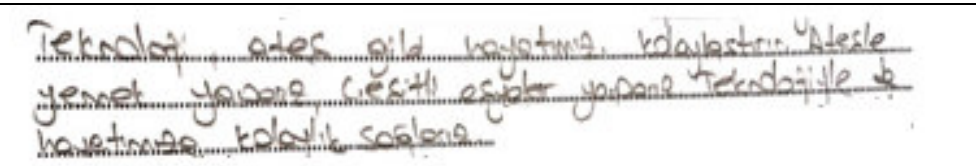 \\
\hline $\begin{array}{l}\text { Enabling fast } \\
\text { and easy access }\end{array}$ & Mother & 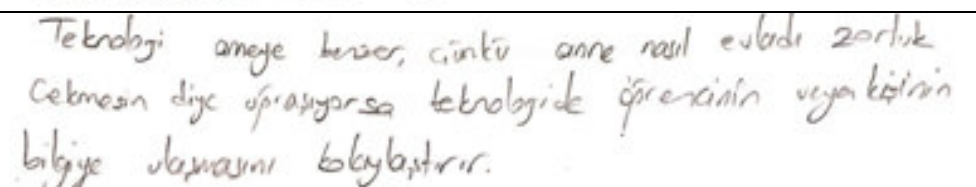 \\
\hline $\begin{array}{l}\text { Providing an } \\
\text { opportunity for } \\
\text { self- } \\
\text { development }\end{array}$ & Fire & 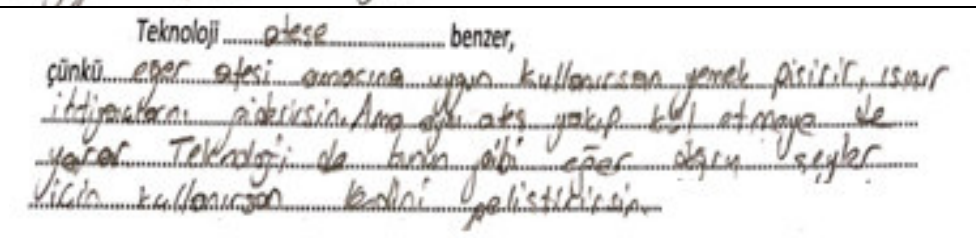 \\
\hline $\begin{array}{l}\text { Having many } \\
\text { different areas } \\
\text { of use/being } \\
\text { useful }\end{array}$ & Sun & 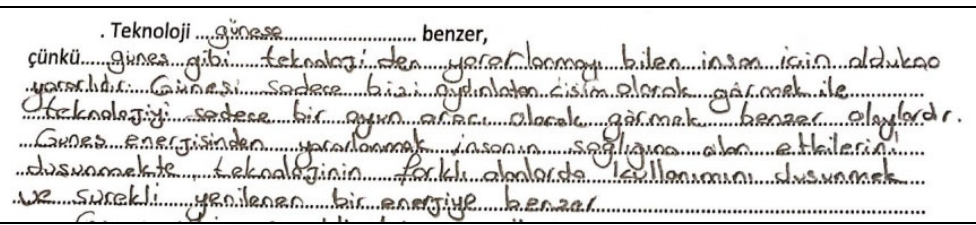 \\
\hline $\begin{array}{l}\text { Being } \\
\text { beneficial }\end{array}$ & Human & 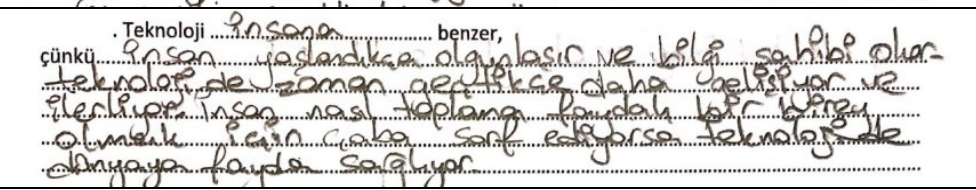 \\
\hline
\end{tabular}

Table 14. The sub-themes and metaphor explanations related to the technology's purposes of use theme in prospective $4^{\text {th }}$ grade teachers

\begin{tabular}{|c|c|c|}
\hline Sub-themes & Metaphor & Explanations \\
\hline $\begin{array}{lr}\text { Being } & \text { both } \\
\text { beneficial } & \text { and } \\
\text { harmful } & \end{array}$ & $\begin{array}{l}\text { sharp/penetrating/infla } \\
\text { mmatory materials }\end{array}$ & 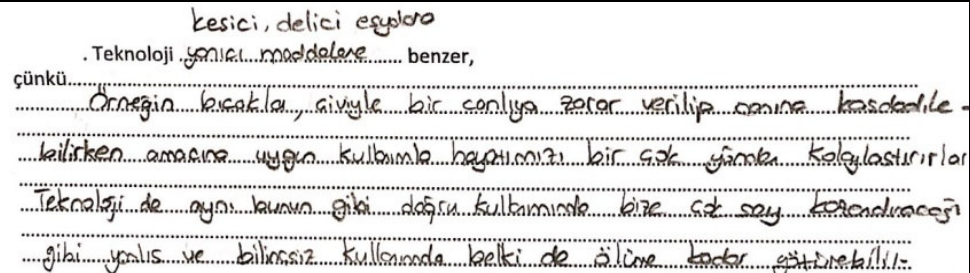 \\
\hline
\end{tabular}


Table 15. The sub-themes and metaphor explanations related to the structural features of technology theme in

\begin{tabular}{|c|c|c|}
\hline Sub-themes & Metaphor & Explanations \\
\hline $\begin{array}{l}\text { Being } \\
\text { comprehensive }\end{array}$ & Ocean & 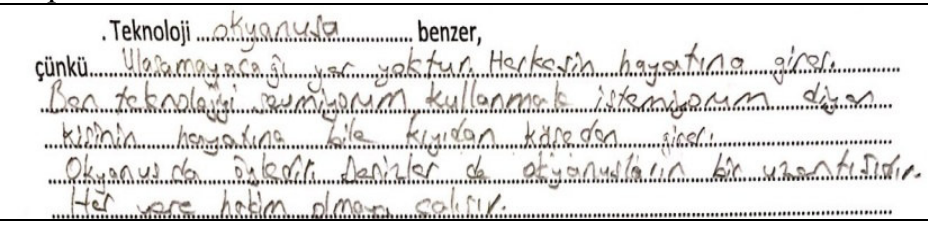 \\
\hline \multirow{5}{*}{$\begin{array}{l}\text { Being constantly } \\
\text { developing }\end{array}$} & Space & 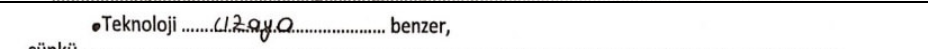 \\
\hline & & 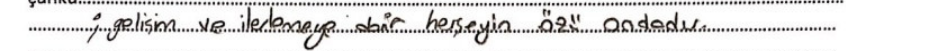 \\
\hline & & 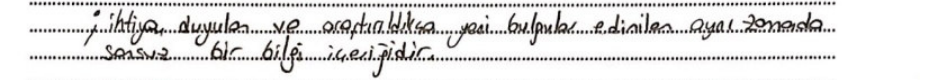 \\
\hline & & 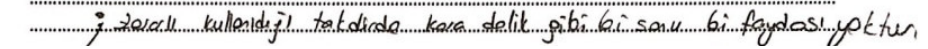 \\
\hline & Chameleon & 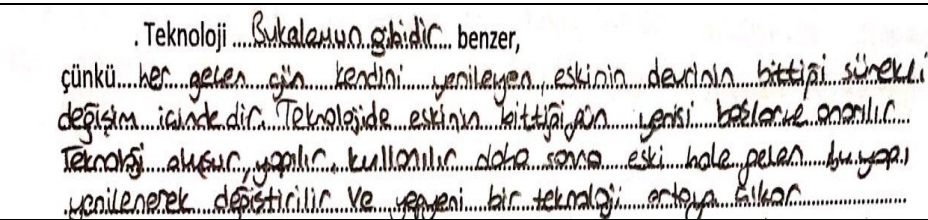 \\
\hline
\end{tabular}

Table 16. The sub-themes and metaphor explanations related to the developing a positive attitude towards technology theme in prospective $4^{\text {th }}$ grade teachers

\begin{tabular}{|c|c|c|}
\hline Sub-themes & Metaphor & Explanations \\
\hline $\begin{array}{l}\text { Being } \\
\text { necessary }\end{array}$ & Heart & 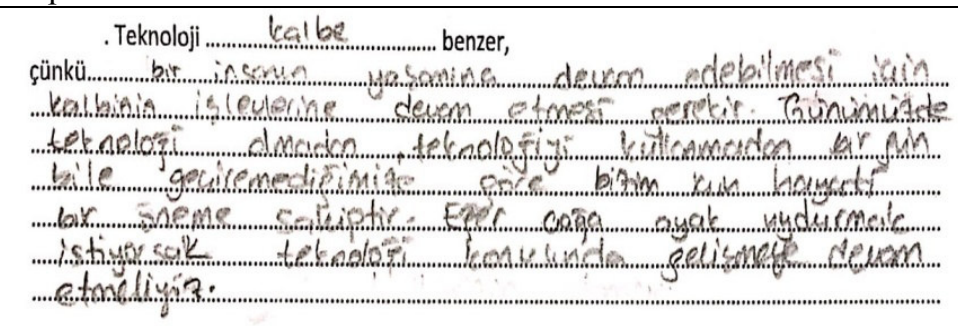 \\
\hline \multirow[t]{2}{*}{$\begin{array}{l}\text { Having the idea } \\
\text { that learning is } \\
\text { inevitable }\end{array}$} & Buzdağ1 & 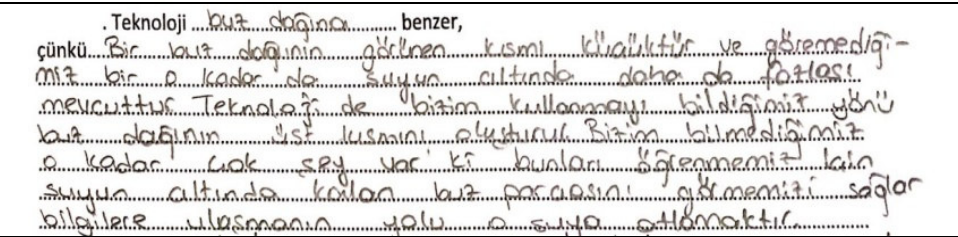 \\
\hline & Brain & 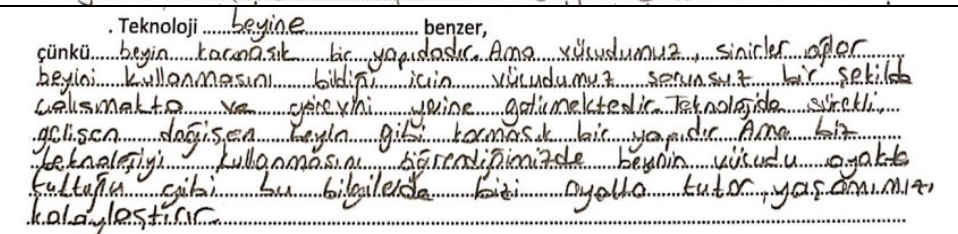 \\
\hline
\end{tabular}

Table 17. The sub-themes and metaphor explanations related to the developing negative attitude towards technology theme in prospective $4^{\text {th }}$ grade teachers

\begin{tabular}{|c|c|c|}
\hline Sub-themes & Metaphor & Explanations \\
\hline $\begin{array}{l}\text { Being an } \\
\text { uncontrolled } \\
\text { power }\end{array}$ & Snowball & 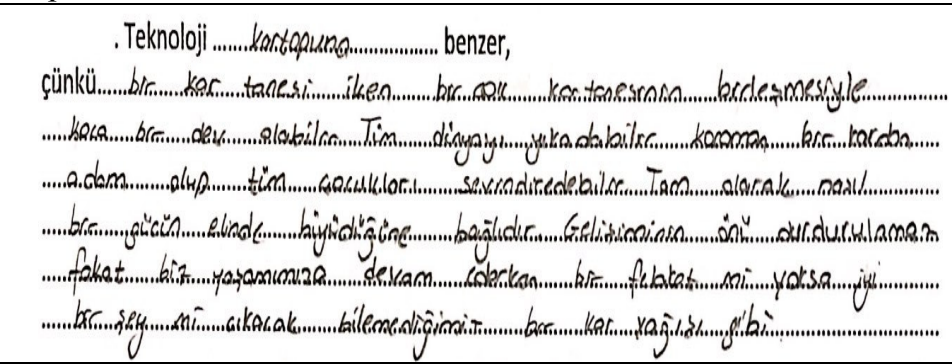 \\
\hline
\end{tabular}




\section{Discussion, Conclusion and Implications}

The purpose of this study was to investigate the prospective mathematics teachers' metaphorical perceptions regarding the concept of technology, and to interpret the metaphors after gathering and placing them in categories (themes and sub-themes) based on their common traits. This revealed the following results:

The perceptions of prospective teachers regarding the concept of technology were composed of eight themes/categories as "The positive effects of technology", "The negative effects of technology", "Technology by the areas of use", "The structural features of technology", "the contributions of technology to the student", "The contributions of technology to the teacher", "Developing a positive attitude towards technology", and "Developing a negative attitude towards technology" in general. It was only the fourth-grade level which did not reveal any results regarding the "The contributions of technology to the teacher" theme. Regarding another result, about the themes: the themes revealed diverse frequencies in each grade level. The frequencies of sub-themes at the second-grade level were respectively (14), (8), (8), (11), (12), (4), (8), (1). While at the third-grade level it was (18), (2), (5), (10), (6), (1), (6), (3) and at the fourth-grade level revealed as (22), (2), (3), (10), (2), (0), (2), (1). When the frequencies regarding sub-themes were investigated, it can be claimed that the prospective teachers contributed to the structural features of technology with equal rates. When the sub-themes were investigated according to the grade levels, the most contributions were made to "The positive aspects of technology", and it was found that this theme was enriched with diverse and various metaphors. Another interesting result is that the sub-themes belonging to the themes "The negative effects of technology", "Technology by its purposes of use", "The contributions of technology to the student", and "The contributions of technology to the teacher" which were found as prominent in the second-grade level, were revealed as having a noticeably lower frequency at the fourth-grade level. As a result, the prospective teachers were found to be mostly considering technology from its positive effects, and from its structural features, and perceived from these aspects. When the literature is investigated, it is safe to claim that in the categorization of the metaphorical perceptions regarding technology, unlike this study, certain general terms were revealed. Hence, it was found that technology was mainly perceived under the categories as "being necessary", "ever-changing", "developing", "being harmful", "being beneficial", "being addictive", "being both beneficial and harmful" (e.g. Arslan \& Zengin, 2017; Erdoğan \& Gök, 2008; Fidan, 2014; Kurt \& Özer, 2013; Kobak \& Taşkın, 2012; Yalçın \& Küçük, 2011; Gök \& Erdoğan, 2010; Karaçam \& Aydın, 2014; Korkmaz \& Ünsal, 2016; Durukan, Hacığulu \& Dönmez-Usta, 2016). In this respect, it can be claimed that this study, when it is investigated in depth and in detail, the technology perceptions of the candidates ( in 8 themes and 159 sub-themes) made contributions from a wide range of aspects. For instance, in the study by Durukan, Hacioğlu, Dönmez-Usta (2016) while the subcategories as development, progress, being infinitive, dissemination were presented under the positive aspects of technology, in this study they were gathered under "the structural features of technology", the facilitation, access, and being beneficial sub-categories were placed under the "positive effects of technology". The addictive category was placed in the negative effects of technology as in Durukan, Hacioğlu, Dönmez-Usta's (2016) study. However, Durukan, Hacioğlu, Dönmez-Usta (2016) investigated the negative aspects of technology under two different titles as being harmful and being addictive, while in this study the negative aspects of technology were investigated in more detail. For instance, the prospective second-grade teachers described the negative aspects of technology (in 8 sub-themes) as "inhibiting thinking", "being addictive", "causing to be insensitive to external stimuli", "risking human life", "being quickly consumed", "causing to become asocial", "getting used to surfing the Internet, and "causing a waste of time". A similar situation can be seen in other studies, as well.

Additionally, in this study, an analysis was conducted of the metaphorical perceptions from the perspectives of grade-levels, themes, and metaphors produced by the prospective teachers. The comparative data regarding these investigations were presented in Table 18 and Table 19 
Table 18. The comparison of metaphorical perceptions based on grade-levels and themes.

\begin{tabular}{|l|c|c|c|c|c|c|c|c|}
\hline \multirow{2}{*}{ Themes } & \multicolumn{6}{|c|}{ Grade-levels } & \multicolumn{2}{|c|}{ Total } \\
\cline { 2 - 11 } & \multicolumn{2}{|c|}{2} & \multicolumn{2}{|c|}{3} & \multicolumn{2}{|c|}{4} & \multicolumn{2}{|c|}{} \\
\cline { 2 - 11 } & $\mathrm{f}$ & $(\%)$ & $\mathrm{f}$ & $(\%)$ & $\mathrm{f}$ & $(\%)$ & $\mathrm{f}$ & $(\%)$ \\
\hline Positive effects of technology & 65 & 26.21 & 48 & 28.57 & 68 & 45.03 & 181 & 31.92 \\
\hline Negative effects of technology & 19 & 7.66 & 2 & 1.19 & 4 & 2.65 & 25 & 4.41 \\
\hline Technology by the purposes of use & 41 & 16.53 & 22 & 13.10 & 17 & 11.26 & 80 & 14.11 \\
\hline Structural features of technology & 81 & 32.66 & 59 & 35.12 & 40 & 26.49 & 180 & 31.75 \\
\hline $\begin{array}{l}\text { The contributions of technology to } \\
\text { student }\end{array}$ & 21 & 8.47 & 13 & 7.74 & 2 & 1.33 & 36 & 6.35 \\
\hline $\begin{array}{l}\text { The contributions of technology to } \\
\text { teacher }\end{array}$ & 6 & 2.42 & 1 & 0.59 & 0 & 0 & 7 & 1.23 \\
\hline $\begin{array}{l}\text { Developing a positive attitude } \\
\text { towards technology }\end{array}$ & 14 & 5.65 & 19 & 11.31 & 15 & 9.93 & 48 & 8.47 \\
\hline $\begin{array}{l}\text { Developing negative attitude towards } \\
\text { technology }\end{array}$ & 1 & 0.40 & 4 & 2.38 & 5 & 3.31 & 10 & 1.76 \\
\hline Total & 248 & 43.74 & 168 & 29.63 & 151 & 26.63 & 567 & 100 \\
\hline
\end{tabular}

The results obtained according to the research data in Table 18 are as follows:

1. The themes with the highest frequency metaphors regarding technology in all of the grade levels were found as "the positive effects of technology", and "the structural features of technology". This rate forms $63.67 \%$ of all metaphors.

2. The theme technology by the purposes of use composes $14 \%$ of all metaphors and is the third most frequent theme.

3. The theme "the structural features of technology" has the highest frequency in second and third-grade levels and the rates were found as close in each grade level.

4. Nearly half of the prospective teachers at the fourth-grade level produced metaphors regarding "the positive effects of technology" theme.

5. Unlike other grade levels the prospective teachers at the fourth-grade level did not produce any metaphors that fall into the theme "the contributions of technology to the teacher".

6. Unlike other grade levels, the teachers at the second-grade level revealed a higher rate of metaphors regarding the negative effects of technology.

7. When the themes in all grade levels were investigated, the highest number of metaphors were produced regarding "the structural features of technology" theme. This rate composes $14.29 \%$ of all metaphors.

8. In total, 567 metaphors were produced. The highest contribution was made by the second-grade level students with a $43.74 \%$ rate. When the number of participants by metaphors was investigated again, the highest rate $(85 / 248=0.34)$ is at the second-grade level. This ratio is $49 / 168=0.29$ at the third-grade level, while it is $39 / 151=0.26$ at the fourth-grade level. According to these rates, the lowest contribution in terms of metaphors was made by the fourth-grade prospective teachers.

9. The most sub-themes were gathered under "the positive effects of technology" theme. The highest number of metaphors were produced by the fourth-grade level prospective students with 21 sub-themes. When the number of participants by grade level was investigated, it was determined that the prospective fourth-grade teachers contributed the highest number of metaphors; this is an interesting result. At this point, it is speculated that this may be because the prospective fourth-grade teachers participate in more classes in which computers are used (including hardware and software information). Also, prospective teachers at the fourth-grade level have more computer assisted mathematics classes throughout their undergraduate education.

10. The number of metaphors in the "developing a positive attitude towards technology" theme showed similarities in all grade levels. The number of metaphors produced by the third-grade level prospective teachers was found as higher. However, it is remarkable that the second-grade level prospective teachers revealed a higher number of sub-themes regarding this theme. Accordingly, it can be claimed that the attitudes of secondgrade level prospective teachers towards technology are more diverse, and they brought different dimensions to the forefront.

11. It was obvious that the prospective second- and third-grade teachers revealed metaphors at similar rates when the themes "the contribution of technology to the student and teacher" were investigated with their sub-themes. On the other hand, the fourth-grade level prospective teachers mentioned the contributions of technology to the student with a comparatively small number of metaphors, and they did not mention the contributions of technology to the teacher at all. 
12. Participants from each grade level revealed similar rates of metaphors regarding "technology use by the purposes of use".

Table 19 presents the investigation of the metaphors produced by the prospective teachers in terms of grade levels and frequencies.

Table 19. The comparison of metaphors in terms of grade-levels and frequencies.

\begin{tabular}{|c|c|c|c|c|c|}
\hline \multicolumn{2}{|l|}{ 2. grade-levels } & \multicolumn{2}{|l|}{ 3. grade-levels } & \multicolumn{2}{|l|}{ 4. grade-levels } \\
\hline Metaphors & (f) & Metaphors & (f) & Metaphors & (f) \\
\hline Human & 22 & Life & 11 & Space & 15 \\
\hline Mathematics & 14 & Time & 8 & Mother & 14 \\
\hline Game & 10 & Brain & 8 & Tree & 9 \\
\hline Life & 8 & Human & 6 & Fire & 8 \\
\hline Tree & 8 & Mathematics & 6 & Ladder & 6 \\
\hline Forest & 7 & Light & 5 & Human & 4 \\
\hline News portal & 7 & Friend & 5 & Tractor & 5 \\
\hline A relative concept & 7 & Bottomless well & 5 & Sun & 5 \\
\hline Encyclopedia & 6 & Science & 5 & Water & 4 \\
\hline Experiment desk & 6 & Sea & 5 & $\begin{array}{l}\text { Enzyme } \\
\end{array}$ & 4 \\
\hline Space & 6 & People's desires & 5 & Sharp/penetrating/inflammatory materials & 4 \\
\hline A tool for entertainment & 5 & Car & 5 & Snowball & 4 \\
\hline World & 5 & Support team & 4 & Traffic signs & 4 \\
\hline Weapon & 4 & Sapling & 4 & Assisting referee & 4 \\
\hline Ocean & 4 & Information & 4 & Wearing makeup & 4 \\
\hline Information & 4 & An endless ocean & 4 & Brain & 4 \\
\hline River & 4 & & & Bukalemun & 4 \\
\hline Endless road & 4 & & & Ocean & 4 \\
\hline School & 4 & & & Cancer & 4 \\
\hline & & & & Sapling & 4 \\
\hline
\end{tabular}

When Table 19 is examined, it can be observed that human and ocean metaphors are used in each grade level to refer to technology. While mathematics and life metaphors are used by the second-and third-grade level prospective teachers, space and tree metaphors are used by the second- and forth-grade level prospective teachers. Another remarkable result is the mother metaphor was only produced by the fourth-grade level prospective teachers. It was found that the metaphors produced by the prospective teachers varied in general. At this point, it can be stated that the prospective teachers emphasized that technology can be harmful because it puts human life at risk by means of the metaphors in which they referred to technology as a weapon, and as sharp/penetrating/inflammable materials. As a result, it can be claimed that prospective mathematics teachers have a positive perception regarding technology.

When the results are investigated as a whole, a situation that is investigated in the related literature attracts attention. The questions which arise are: "Do the ideas of individuals regarding technology change as their level of education rises?" and "Does the awareness of individuals regarding the harms of technology increase as their ages and level of education increase?" Gök and Erdoğan (2010), and Karadeniz (2012) revealed at the end of their studies, that the participants' ages do not have any effect on their perceptions regarding technology. In the present study, the participants who produced more metaphors on the negative effects of technology were revealed as the second-grade level prospective teachers. In other words, the prospective second-grade teachers emphasized the negative effects of technology more. This result is in contradiction with the results of the studies by Rennie \& Javis (1995), and Karaçam \& Aydın (2014). However, the attitudes of prospective teachers towards technology were positive in general. In a study by Durukan, Hacığlu and Dönmez-Usta (2016) the metaphors revealed by the prospective teachers in the negative aspects of technology category were being harmful $(15 \%)$ and being addictive (85\%). As stated previously, the negative aspects of technology theme was investigated in more detail in this study. Fidan (2014) stated in his study that prospective teachers regarded technology as being harmful more than being beneficial. Berigel et al. (2012) stated that specific social networks are important tools for the prospective teachers' daily activities, such as communication and entertainment, and this is supported with the explanations of prospective teachers about "social networks harm individuals". In the addiction category, the social network addiction, internet, computer, and technology addiction are found together (Das \& Sahoo, 2011, Kuss \& Griffits, 2011). In this study, it was revealed that prospective mathematics teachers had a positive perception regarding technology. However, when the sub-themes in all grade levels regarding "the negative aspects of technology" theme were investigated, it was found that the prospective teachers highlighted technology as being a social phenomenon (Smith, 1994: 6). Similarly, in Batur \& Uygun's (2012) study, the individuals who revealed positive views regarding technology also stated that it was addictive, and had negative 
effects on individuals' social life since it made them lazy. In this respect, it was revealed in the present study that the prospective teachers highlighted the negative aspects of technology by producing metaphors on its being addictive, and their negative perceptions supported the literature.

The fact that prospective teachers perceived technology as both positive and negative has been associated with their use of technology and their experiences (Fidan, 2014). According to Ferdening (2007), this regard of technology as both positive and negative could be because the trainers did not associate technology with class levels. Therefore, it can be stated that prospective teachers' having a negative attitude towards technology can partly be based on the lecturers' insufficient use and association of technology during the course (Fidan, 2014). Some studies (Dupagne \& Krendl, 1992; Dell \& Disdier, 1994) revealed that the positive attitude towards technology is also directly linked with prospective teachers' technology courses. Lie (2007) explained this situation by citing the advantages and disadvantages of technology. In this respect, in one of the results obtained in this study, we see the contributions of technology to the student and teacher, and the positive and negative attitudes towards technology, along with the positive and negative aspects of technology. Hence, the studies in the literature are observed as making similar inferences (e.g. Lie, 2007; Kurt \& Özer, 2013; Fidan, 2014, Durukan, Hacıŏlu, \& Dönmez-Usta, 2016).

In the study by Durukan, Hacioğlu, and Dönmez-Usta (2016), the prospective teachers associated the "human" (10) and "child" (6) sources with technology more under the sub category development. In the study conducted by Fidan (2014), when the categories were considered as a whole, the metaphors that were produced more frequently were child, water, human, and life. When the categories were considered separately, the most frequent ones were child, water, book, monster, medicine, and assistant. In the study by Kurt and Özer (2013), the metaphors that were produced more frequently were determined as "tool" (15), and "life" (10). When the categories were investigated separately, the highest number of metaphors was produced under the category of "both beneficial and harmful"." ". In addition to this, the most frequently produced metaphor was "life" in "the necessary technology" category; and in the "making life easier technology" it was found as "tool". In a study by Korkmaz and Ünsal (2016), the most frequent metaphor was the perception of technology as a medicine $(\mathrm{f}=8)$. It was understood that a large proportion of teachers perceived technology as a solution to the problems that they faced. Karaçam and Aydın's (2014) study determined that the students mostly used "water (14)", "human (11)", "plane (8)", "sun (6)", "moon (5)", "light (5)", "lamp (5)", and "computer (5)" metaphors, and mostly highlighted "being beneficial", "development", and "constant change" dimensions. Karaçam \& Aydın (2014) stated that the participants had a generally positive perception towards technology. The students had an effect on society due to their perceptions, such as the benefits and harms of technology, its necessity, and perceiving technology as a creative process. How the students affect society depends on their perceptions regarding the development and change of technology. Similarly, DiGironimo (2010) determined that the students mostly emphasized: "technology as tools produced by humans" and "the effects of technology on society", and "technology as the creative process" was emphasized the least.

Erdoğan and Gök (2008) in their study revealed that the prospective teachers perceived technology mostly as a concept of "developing"; "making our life easier" was mentioned the least. When the categories that form technology are considered as a whole, the metaphors with the highest frequency are chameleon, human, and food. When the categories formed regarding technology are considered separately, the metaphors with the highest frequency are water, chameleon, human, monster, cigarette, bacteria, medicine, cheetah, tiger, magic box, and robot. In this study, the medicine metaphor was used for technology, but since it is lower in number $(<4)$ it was not included in the general evaluation. In the study, technology was mostly explained through "human" (22), "space" (15), "mathematics" (14), "mother" (14), "life" (11), "game" (10), and "tree" (9) metaphors. The highest number of metaphors was produced within the themes of "the positive effects of technology" and "the structural features of technology", while the lowest number of metaphors was developed within the theme of "the contributions of technology to the teacher". Prospective second-grade teachers were found to have produced metaphors mostly in the themes of "structural themes of technology", and "positive effects of technology". The sub-themes where the highest number of metaphors were produced - according to the structural features theme were constantly developing, being comprehensive, being dynamic and changing, and being progressive. The subtheme according to the purposes of use produced the metaphors of being both beneficial and harmful, and conscious use. The sub-theme regarding positive effects produced metaphors of directing to do research and make discoveries, providing a chance for self-development, being present in every aspect of our life, having many different areas of use, being beneficial, and enabling fast and easy access. Regarding negative effects the metaphor was risking human life; in terms of developing a positive attitudes it was being necessary. It was revealed that the prospective third-grade teachers also produced more metaphors in the "structural features of technology" and "the positive effects of technology". Whereas the themes are the same, interestingly enough the sub-themes were diversified. At this point, it can be claimed that the third-grade level prospective teachers provided more diverse views, and approached these views from different perspectives towards the theme of the positive effects of technology. The sub-themes in which more metaphors were produced in terms of positive 
effects were being beneficial, providing an opportunity for self-development, making life easier, and being present in every aspect of life; according to the purposes of use the sub-themes were being both beneficial and harmful, useful in teaching, and the importance of controlling it; in terms of structural features the sub-themes were being comprehensive, being constantly developing, being dynamic and changing; in terms of developing a positive attitude the sub-themes were enjoying spending time, feeling the need to follow the latest technologies, having the idea that learning is inevitable. As in other grade-levels, the prospective teachers at the fourth-grade level also produced more metaphors within the themes of "the structural features of technology" and "the positive effects of technology". Even if the themes are the same, it is clear that the sub-themes differed. At this point, it can be claimed that the third-grade level prospective teachers provided more diverse views and approached these views from different perspectives towards the positive effects of technology theme. The subthemes in which the highest number of metaphors were produced within in terms of the positive effects were making life easier, enabling fast and easy access, providing an opportunity for self-development, having many different areas of use, and being beneficial; in terms of the purposes of use the sub-themes produced were being both beneficial and harmful; in terms of structural features the sub-themes were being comprehensive, and being constantly developing; in terms of developing a positive attitude the sub-themes were being necessary, having the idea that learning is inevitable; in terms of developing negative attitudes the sub-theme was being uncontrolled power. The results obtained in this study revealed similarities with the literature. In this respect, the results of the study contributed to technology perceptions by adding new themes and sub-themes.

Another result is that the prospective teachers have a perception that technology contributes to the rise of civilization, and they produced metaphors in line with this. This finding confirmed the statement of Balaam \& Veseth (2000) as "the developing or developed countries' consideration that technological development and innovation are the most important factors that affect the economic growth and development in all areas".

With this study, it has been revealed that the perceptions of the prospective mathematics teachers regarding technology are quite diversified and mostly positive. It can be stated that the results of this study revealed the general traits of prospective mathematics teachers regarding technology. In this study, it has been concluded that metaphors can be used as an important research tool to explain the perceptions of prospective teachers regarding "technology". As Gunter, Gunter \& Wiens (1998) stated in their study, computers have infiltrated into all areas of our life. Therefore, the prospective teachers need to be prepared for the workforce by having sufficient computer skills. Along with this, in the undergraduate programs of faculties of education, there needs to be at least one course regarding computer literacy in relation to the mathematics course, and the prospective teachers should be able to effectively integrate technology into mathematics teaching.

In order to achieve this;

1. During the pre-service training provided to the prospective teachers, training environments should be developed in which the prospective teachers can develop positive attitudes towards technology.

2. The prospective teachers should be enabled to use technology within their courses during teacher training.

3. In order for prospective teachers to develop positive attitudes regarding technology, the lecturers should set good examples for the prospective teachers in terms of using technology efficiently during courses, and including varied technologies in their courses.

4. Similar studies should be conducted on lecturers in the faculty of education, mathematics teachers and students. Their perceptions regarding technology can be determined, and the results can be compared. In this way, in order to create environments that support technology in mathematics teaching, the proper contents and materials can be determined, and developing a positive view towards mathematics can be assured.

\section{References}

Arslan, A. \& Zengin, Z. (2017). Fen bilgisi öğretmen adaylarının teknoloji kavramına ilişkin algılarının metafor analizi yoluyla incelenmesi. The Journal of Academic Social Science Studies. Doi number:http://dx.doi.org/10.9761/JASSS6884

Balaam, D.N. \& Veseth M. (2000). Introduction to International Political Economy, Second Edition, New Jersey: Prentice Hall.

Batur, Z, \& Uygun, K. (2012). İki neslin bir kavram algısı: teknoloji. Uşak Üniversitesi Sosyal Bilimler Dergisi, 5(1), 74-88.

Berigel, M., Kokoç, M. \& Karal, H. (2012). Exploring pre-service teachers' level of social networking sites addictive tendencies. Eğitim Arastırmaları-Eurasian Journal of Educational Research, 49/A, 215-228.

Çelik, H. C. \& Kahyaoğlu M. (2007). İlköğretim Öğretmen Adaylarının Teknolojiye Yönelik Tutumlarının Kümeleme Analizi. Türk Eğitim Bilimleri Dergisi, 4 (5), 571-586.

Das, B. \& Sahoo, J. S. (2011). Social networking sites-A critical analysis of its impact on personal and social life. International Journal of Business and Social Science, 2(14), 222- 228.

Dell, A. G.\& Disdier, A. (1994). "Teaching future teachers to enhance teaching and learning with technology." in J. Willis, B. Robin, \& D. A. Willis (Eds.), Technology and Teacher Education Annual 1994: Proceedings 
of SITE94-Fifth Annual Conference of the Society for Technology and Teacher Education (pp. 178-182), Charlottesville, VA: Association for the Advancement of Computing in Education.

DiGironimo N. (2010). What is Technology? Investigating Student Conceptions About The Nature Of Technology. International Journal of Science Education. 33(10), 1337-1352, doi:10.1080/09500693.2010.495400.

Dupagne, M.\& krendi, K.A. (1992). Teachers' attitudes toward computers: A review of the literature. Journal of Research on Computing in Education, 24 (3), 420- 429.

Durukan, Ü.G., Hacioğlu, Y. \& Dönmez-Usta, N. (2016). Bilgisayar ve Öğretim Teknolojileri Öğretmeni Adaylarının "Teknoloji”" Algıları. Bilgisayar ve Eğitim Araştırmaları Dergisi. 4(7), 24-46. DOI: $10.18009 /$ jcer. 21565 .

Erdoğan, T. \& Gök, B. (2008). Sınıf Öğretmeni Adaylarının Teknoloji Kavramına İlişkin Algılarının Metafor Analizi Yoluyla İncelenmesi. In Proceedings of 8th International Educational Technology Conference (pp.1071-1077). Eskişehir, Turkey.

Fidan, M. (2014). Öğretmen Adaylarının Teknoloji Ve Sosyal A ̆g Kavramlarına İlişkin Metaforik Algıları. International Journal of Social Science, 25(I) , 483-496. Doi number: http://dx.doi.org/10.9761/JASSS2229

Gök, B. \& Erdoğan, T. (2010). Investigation of Pre-Service Teachers' Perception About Concept Of Technology Trough Metaphor Analysis. The Turkish Online Journal of Educational Technology, 9(2), 145-160.

Gunter G. A., Gunter, R. E. \& Wiens, G. A. (1998). Teaching pre-service teachers technology: An innovative approach. ERIC Number: ED421112

Karaçam, S. \& Aydın, F. (2014). Ortaokul Öğrencilerinin Teknoloji Kavramına İlişkin Algılarının Metafor Analizi. Gaziantep University Journal of Social Sciences. 13(2):545-572.

Karadeniz Ş. (2012). School administrators, ICT coordinators and teachers' metaphorical conceptualizations of technology. Education. 2 (5), 101-111.

Kobak, M. \& Taşkın, N. R. (2012). Prospective Teachers' Perceptions of Using Technology in Three Different Ways. Procedia - Social and Behavioral Science. 46, 3629-3636.

Korkmaz, F. \& Ünsal, S. (2016). Okul Öncesi Öğretmenlerin “Teknoloji” Kavramına İlişkin Metaforik Algılarının İncelemesi. Mustafa Kemal Üniversitesi Sosyal Bilimler Enstitüsü Dergisi. 13(35). 194-212.

Kurt, A. A. \& Özer, Ö. (2013). Metaphorical Perceptions of Technology: Case of Anadolu University Teacher Training Certificate Program. Ë̈itimde Kuram ve Uygulama, 9(2), 94-112.

Kuss, D. J. \& Griffiths, M. D. (2011). Online Social Networking and Addiction-A Review of the Psychological Literature. International Journal of Environmental Research and Public Health, 8, 3528-3552.

Küçük, M. \& Yalçın, Y. (2011). Sınıf öğretmeni adaylarının teknoloji kavramıyla ilgili metaforları (Investigation of primary student teachers' perceptions about the concept of technology through metaphor). Paper presented at 10th Classroom Teachers and Education Symposium, Sivas, Turkey.

Miles, M. B. \& Huberman, A. M. (1994).Qualitative Data Analysis (2. bask1). Thousand Oaks, CA: SAGE.

Moreland, J. (2004). Putting students at the centre: Developing effective learners in primary technology classrooms. Set. (1), 37-43.

Öksüz, C., Ak, Ş. \& Uça, S. (2009). İlköğretim Matematik Öğretiminde Teknoloji Kullanımına İlişkin Algı Ölçeği. Yüzüncü Yll Üniversitesi Eğitim Fakültesi Dergisi. VI (I), 270-287.

Raat, J. H. \& de Vries, M. (1985). What do 13 - year old students think about technology? The conception of and the attitude towards technology of 13 - year old girls and boys. Eindhoven University of Technology, The Netherlands. (ERIC Document Reproduction Service No. ED 262-998)

Rennie, L. \& Jarvis, T. (1995). Children's choice of drawing to communicate their ideas about technology. Research in Science Education, 25 (3), 239- 252.

Saban, A., Koçbeker, B. N. \& Saban, A. (2006). Öğretmen Adaylarının Öğretmen Kavramına İlişkin Algılarının Metafor Analizi Yoluyla İncelenmesi. Kuram ve Uygulamada Eğitim Bilimleri. 6 (2), 461-522.

Saygıner, Ş. (2016).Öğretmen Adaylarının Bilgisayar Yeterlilik Düzeyleri İle Teknolojiye Yönelik Algıları Arasındaki İlişkinin Çeşitli Değişkenler Açısından İncelenmesi. Mustafa Kemal Üniversitesi Sosyal Bilimler Enstitüsü Dergisi. 13(34), 298 - 312.

Smith, K. (1994). New Direction in Research and Technology Policy: Identifying the Key Issues, Step Report.

Şahin İzmirli, O. \& İzmirli, S. (2010). Technology Metaphors of Prospective Teachers. In J. Herrington \& C. Montgomerie (Eds.), Proceedings of EdMedia: World Conference on Educational Media and Technology 2010 (pp. 2560-2564).

Yavuz Konokman, G., Yanpar Yelken, T. \& Sancar Tokmak, H. (2013). Sınıf öğretmeni adaylarının TPAB'lerine ilişkin algılarının çeşitli değişkenlere göre incelenmesi: Mersin üniversitesi örneği. Kastamonu Eğitim Dergisi, 21(2), 665-684.

Yıldırım, A. \& Şimşek, H. (2008) Sosyal Bilimlerde Nitel Araştırma Yöntemleri, Ankara: Seçkin Yayınevi. 